\title{
أثر استراتيجيتي كارول وأشور في تحصيل قواعد اللغة العربية لاى طالبات الصف الخامس الأدبيّ م.د مبا حامد حسين
}

\section{جامعة بغداد/كلية التربية ابن رشد للعلوم الإنسانية}

الملخص:

يرمي البحث تعرف أثز استراتيجيتي كارول وآثنور في تحصيل طالبات الصف الخامس الادبي في مادة به تحصيل طالبات الصف تقيس تحصيلياً ، اختباراً الباحثة أعدت البحث مرمى قواعد اللغة العربية، ولتحقيق الخامس الأدبيّ في قواعد اللغة العربية ، واختارت الباحثة عينة مكونة من ( ـ ج) طالبة من طالبات مدرسة الانفال

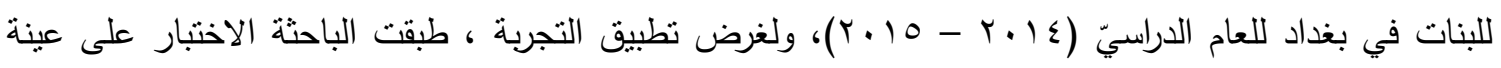

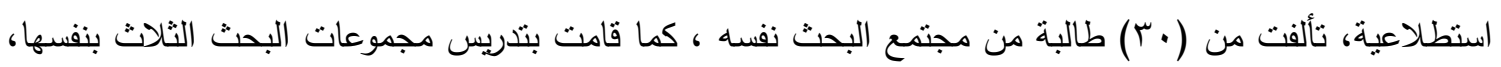
وبعد تحليل البيانات باستعمال معامل ارتباط بيرسون، ومعامل الصعوبة، وقوة التميز ، ومعادلة الفا كرونباخ. وفي ضوء ذلك توصلت الباحثة إلى النتائج الاتية : 1- تفوق طالبات المجموعة التجريبية الأولى ، اللائي درسن بإستراتيجية كارول على طالبات المجموعة التجريبية

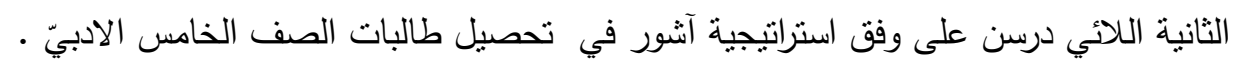

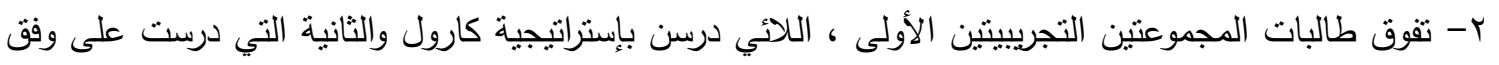

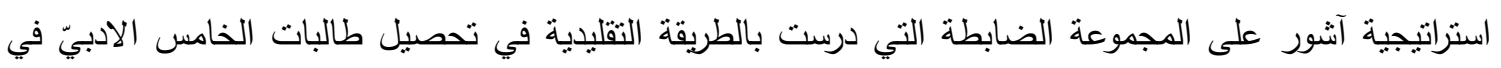
مادة قواعد اللغة العربية . وفي ضوء نتائج البحث خرجت الباحثة بعدد من الاستنتاجات منها:

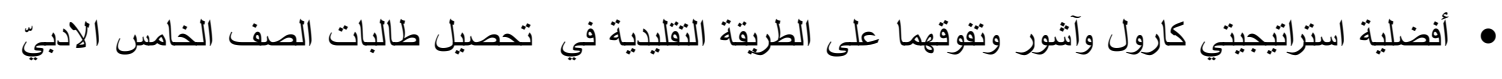
في قواعد اللغة العربية .

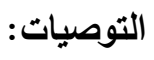
وفي ضوء النتائج أوصت الباحثة بعدد من التوصيات ، منها : • إقامة دورات تدريسية وندوات للمدرسين على كيفية استعمال استراتيجيتي كارول وآثور على وفق الظروف المتاحة في تدريس المقرر الدراسيّ. 
يكاد ضعف الطلبة في مادة قواعد اللغة العربية أن يكون شاملاً وعاماً ، فهو لا يقتصر

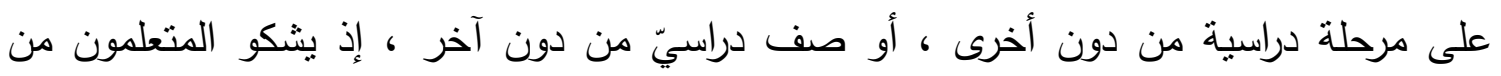

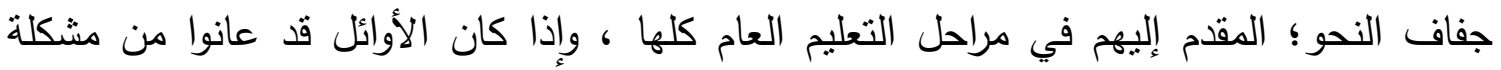

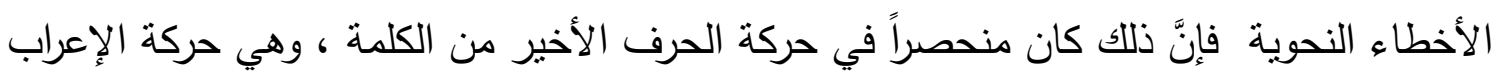

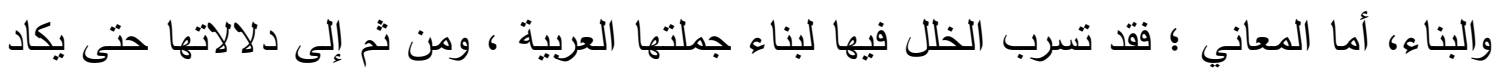
هذا الخلل والتشويه أن يفقدها صفة الانساب إلى العربية ، وهناك أسباب أخرى جعلت من قواعد

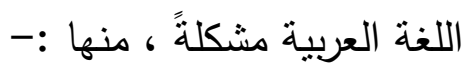
ا- إنَّ مادة قواعد اللغة العربية كانت والى عهد قِِِيب تدرس بوصفها هدفاً مقصوداً لنفسه، فتسرب ذللك إلى أذهان الطلبة من أنَّ قواعد النحو العربيّ غايةً، وليست وسيلة لخدمة معاني اللغة وآدابها. r- الطريقة التقليدي التي تخضع إليها قواعد اللغة العربية في تدريسها إلى الجانب النظري

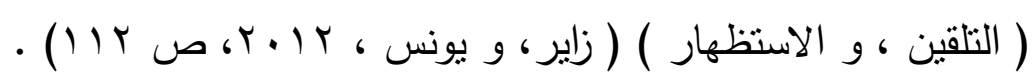
r- إنّ تدريس قواعد اللغة العربية لم يكن مستتداً إلى أي أسلوب من أساليب التعلم الذاتيّ ، ممّا

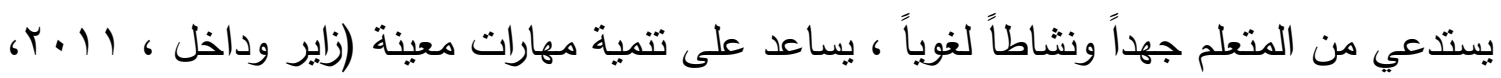
ص (1)

وقد اجمعت الدراسات المعاصرة في العراق أغلبها على أنَّ قواعد اللغة العربية اكبر مشكلات

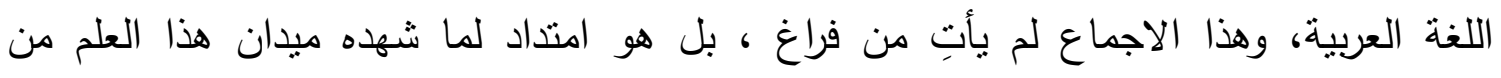

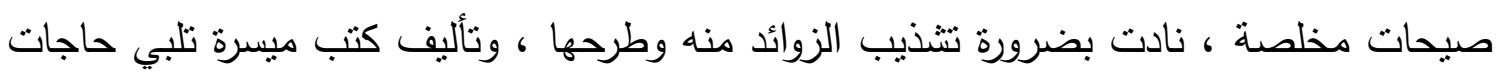

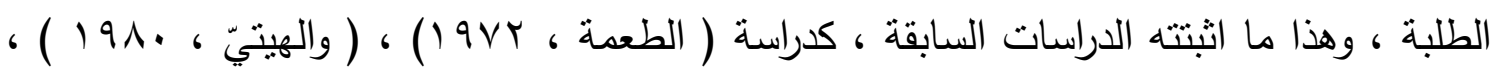

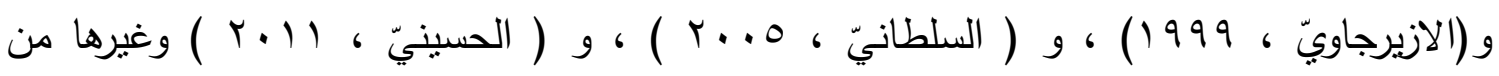
الدراسات . وما زال تدريس قواعد اللغة العربية مستتداً إلى طرائق تقليدية تعتمد، على استظهار القاعدة بعد

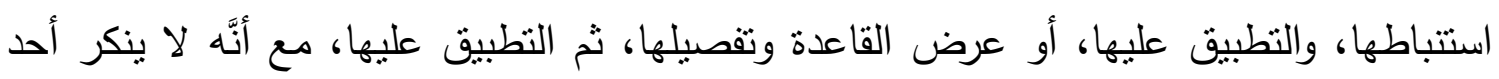
قيمة هاتين الطريقتن في ندريس قواعد اللغة العربية . ومّما سبق تتجلى مشكلة البحث في السؤال الأتي : هل لإستراتيجيتي كارول وآثور أثر في تحصيل طالبات الصف الخامس الأدبيّ في مادة قواعد اللغة العربية ؟ 
إنَّ اللغة العربية هي المظهر اللغويّ لكتاب اله الخالد الرائد وهو ( القرآن الكريم ) والذي

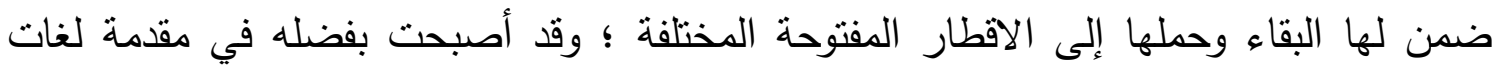

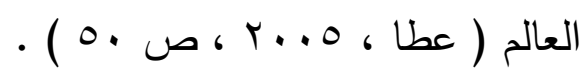
والقواعد النحوية تُعدُ أساس اللغة العربية ؛ لأنَّا وسيلة لضبط الكلام ، وصحة النطق

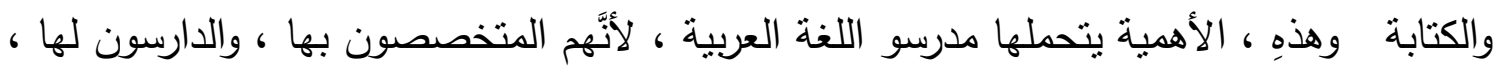

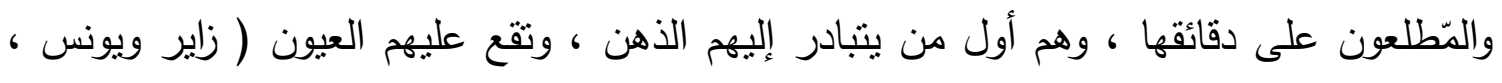

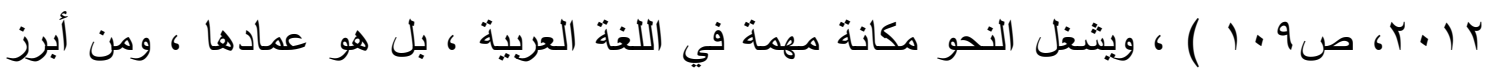

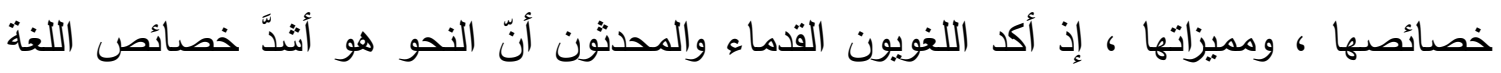
العربية ، وهو المعول عليه في الكلام من ناحية التمييز بين دلالات الصيغ والتزاكيب اللغوية. وللقواعد النحوية منزلة كبيرة في العلوم اللغوية كمنزلة الدستور في القوانين الحديثة ، فهو دهوليه

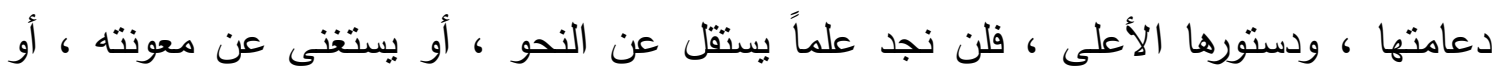

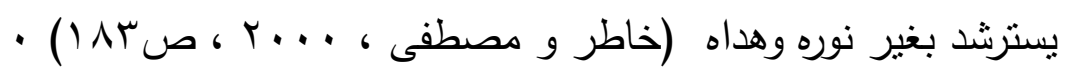

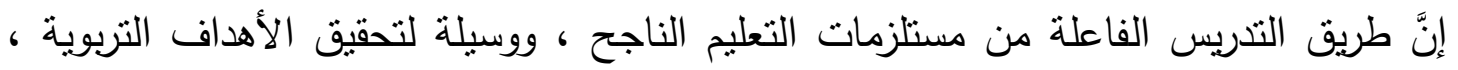
وأداة تعليمية مهمة ينظم بها سلوك المتعلم وأنشطته المعرفية ، وتسهم طريقة التدريس في ربط ،

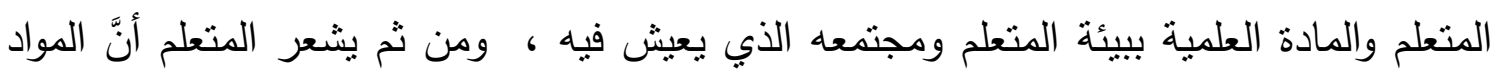

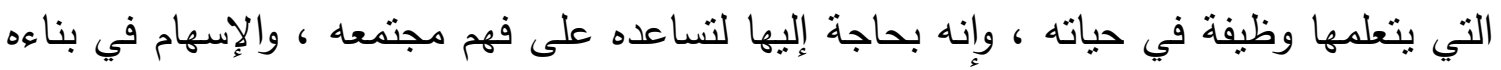

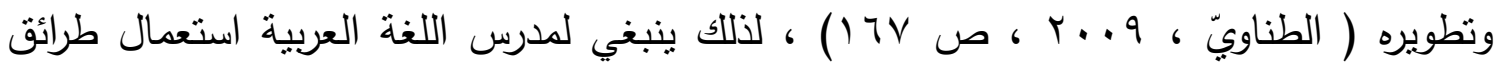

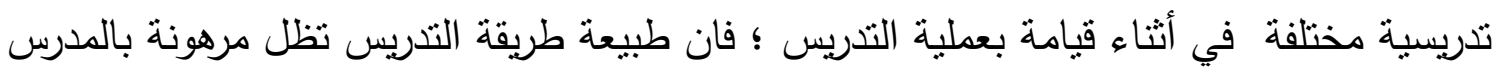

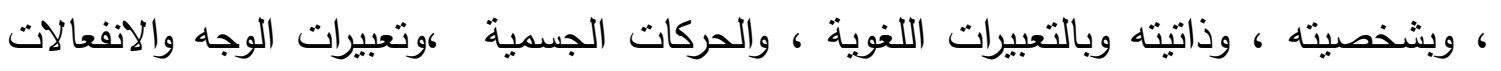

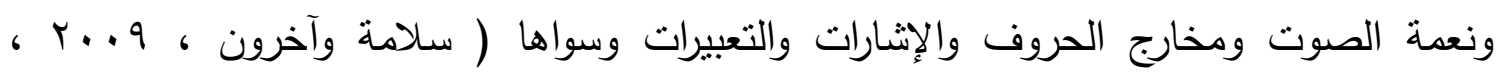

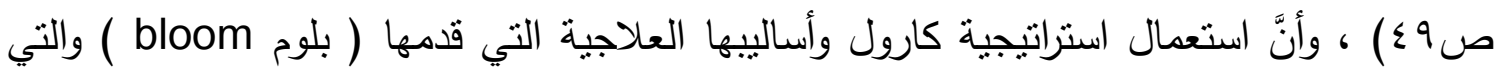
تركز أساسا في ما يعتقد بلوم ( bloom ) ، بأنه يمكن وضع مستوى معين لإتقان التعلم لاى كائ

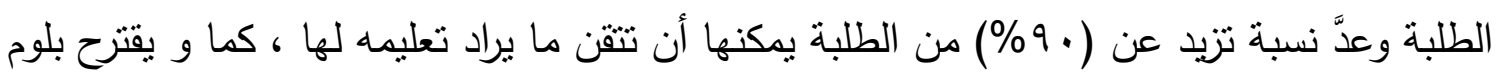

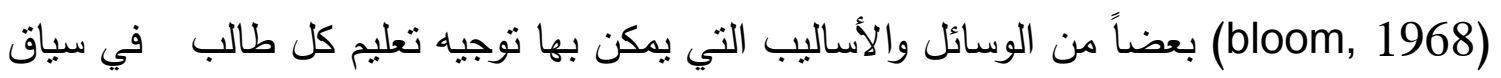

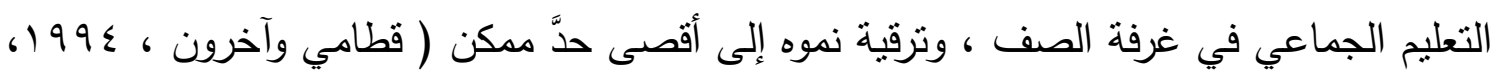

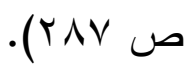


أما استراتيجية آنشور فإنَّها تركز في تحديد الخطوات أو الاجراءات التي يقوم بها المعلمون

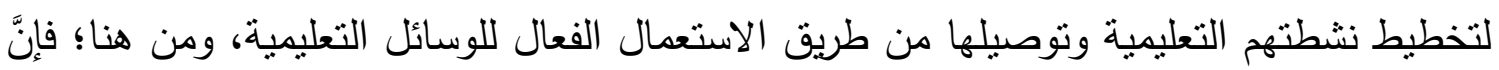

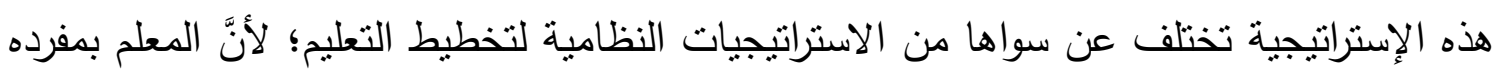

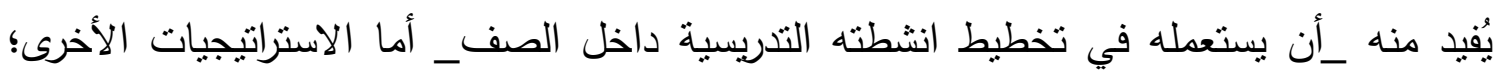
فتحتاج إلى فريق من المتخصصين لتصميم الأمور المتعلقة بالأنظمة التعليمية، من تحليل

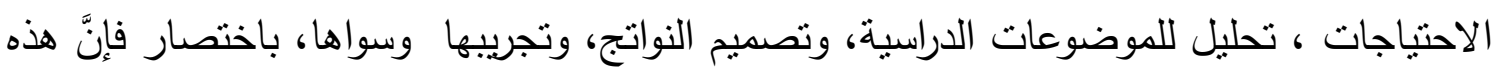
الاستراتيجية تستعمل على مستوى محدود من قبل المعلم الواحد للتخطيط اليومي باستعمال الوسائل

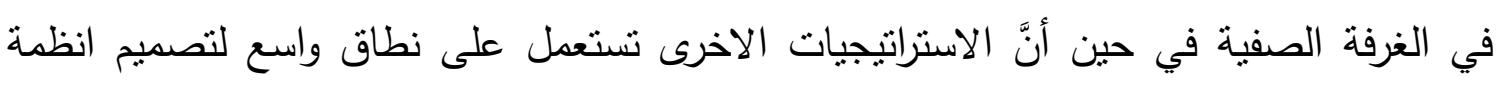

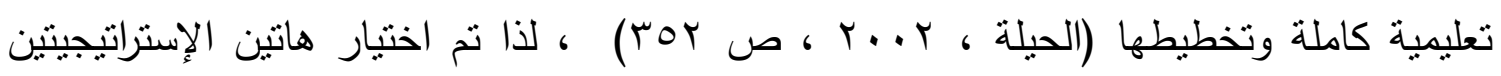

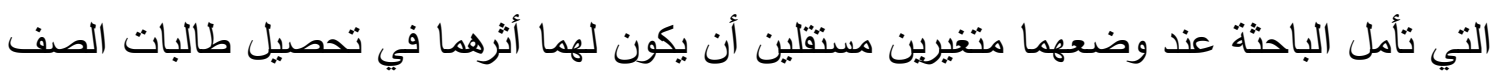

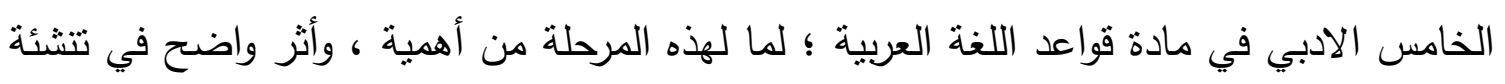
المتعلمات ، وتكوين شخصياتهن، وميولهن، واتجاهاتهن.

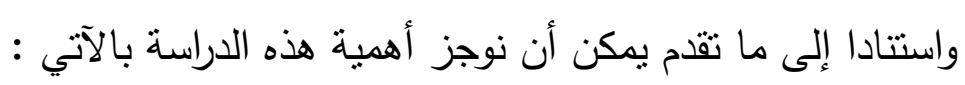

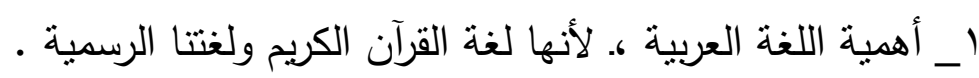

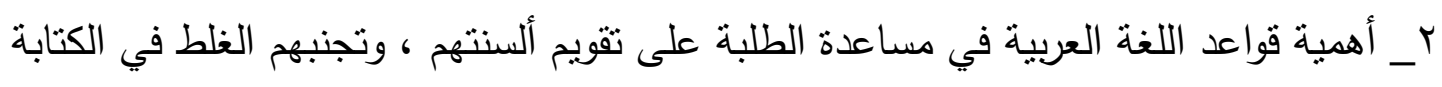

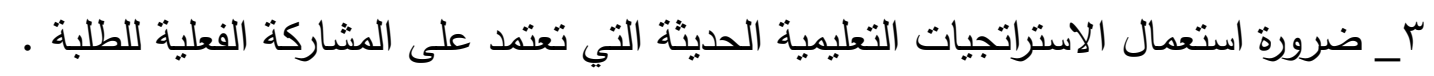
ع_ أهمية المرحلة الدراسية للصف الخامس الأدبيّ .

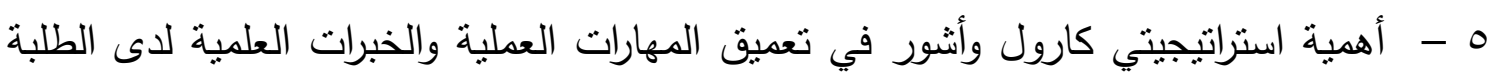

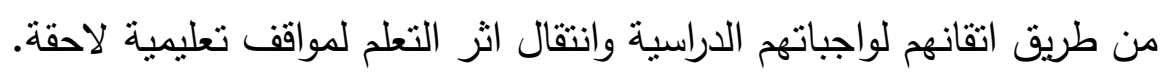

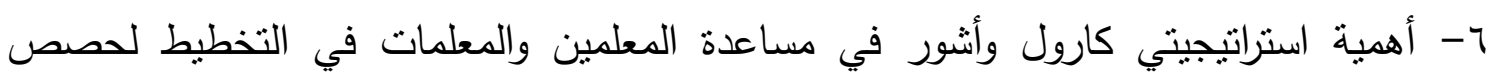

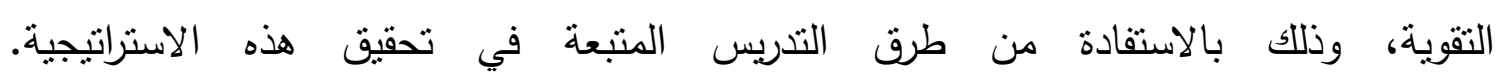

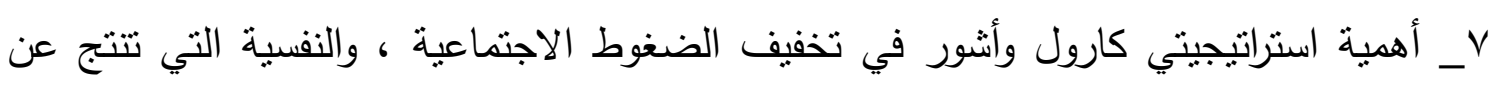
تقصير الطلبة في التحصيل والمساهمة في تحسين مستواهم النفسي والاجتماعي ، إسعادهم وإسعاد

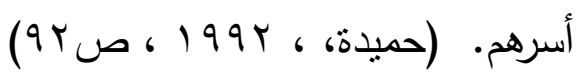

$$
\begin{aligned}
& \text { مرمى البحث : } \\
& \text { يتجلى هدفي البحث في معرفة: }
\end{aligned}
$$

' ـ أثر استراتيجية كارول في تحصيل طالبات الصف الخامس الأدبيّ في قواعد اللغة العربية . 
بـ أثر استراتيجية اشور في تحصيل طالبات الصف الخامس الأدبيّ في قواعد اللغة العربية. فرضيات البحث : ا. ليست هناك فروق ذات دلالة إحصائية عند مستوى دلالة ( ه.، •) وبين متوسط درجات طالبات المجموعة التجريبية الأولى اللائي درسن قواعد اللغة العربية على وفق استراتيجية كارول (اتقان التعلم) ومتوسط درجات المجموعة التجريبية الثانية التي تدرس على وفق استراتيجية آنتور .

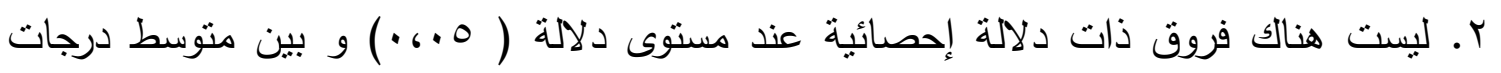

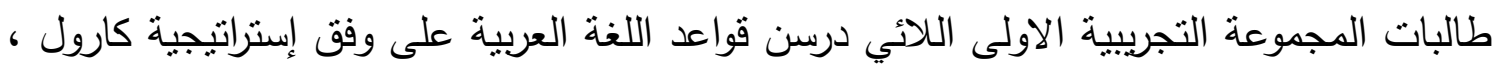
ومتوسط درجات طالبات المجموعة الضابطة التي تدرس بالطريقة التقليدية في قواعد اللغة العربية . r. ليست هنالك فروق ذات دلالة إحصائية بين متوسط درجات طالبات المجموعة التجريبية الثانية

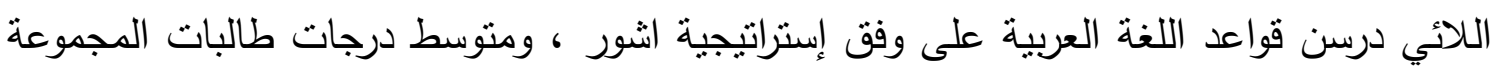
الضابطة التي تدرس بالطريقة التقليدية في قواعد اللغة العربية . حدود البحث: يقتصر هذا البحث على : ا. طالبات الصف الخامس الأدبيّ في المدارس الاعدادية والثانوية النهارية في مدينة بغداد. r. عدد موضوعات كتاب قواعد اللغة العربية المقرر تدريسه في العراق لطالبات الصف الخامس

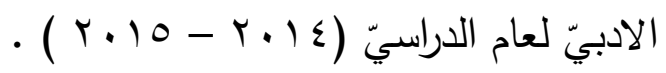

$$
\begin{aligned}
& \text { تحديد المصطلحات: } \\
& \text { أولًا/الإستراتيجية، عرفها كلٌ من : }
\end{aligned}
$$

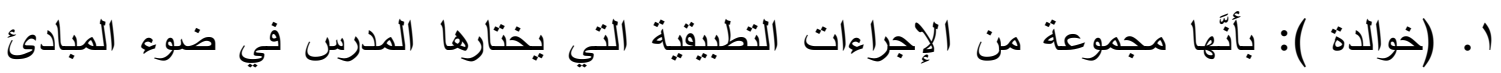

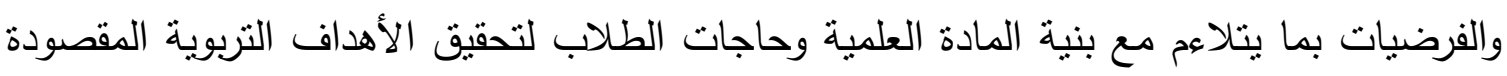

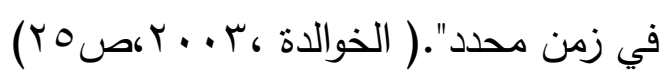

r.(شبر وآخرون ) : بأنّها مجموعة من الإجراءات والوسائل التي تستخدم من المدرس لتمكين

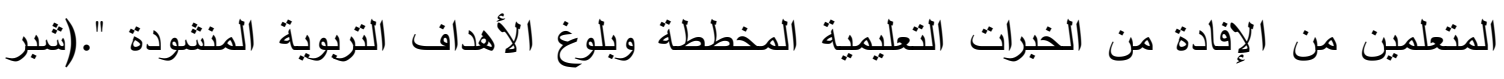

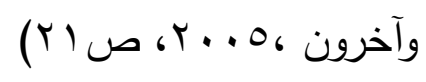

التعريف الاجرائيّ : مجموعة من الخطوات المتسلسلة التي توظفها الباحثة لإعداد خطط دراسية لتدريس طالبات الصف الخامس الأدبيّ الواردة في الفصل الأول والثاني والثالث من كتاب قواعد الأد اللغة العربية ، واختبار الأساليب التدريسية ، والوسائل التعليمية المناسبة. 
ثانياً/ إستراتيجية كارول، عُرفها كل من:

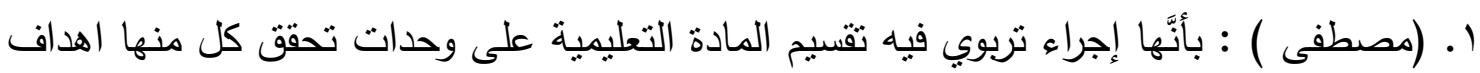
تعليمية معينة، ولا يتم الانتقال من وحدة إلى أخرى إلا بعد إتقان الوحدة السابقة، ويحدد مستوى لرئه الاتقان كحد أدنى ينبغي على المتعلم الوصول اليه ، ويتم التحقق من خلادل الاديه الاداء بتطبيق اختبارات تحصيلية وتطبيق اجراءات علاجية للوصول بالمتعلم غير المتقن الى مسنوى الاتقان

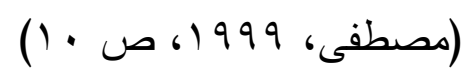

المحدد.

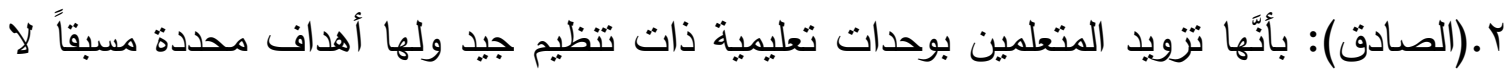

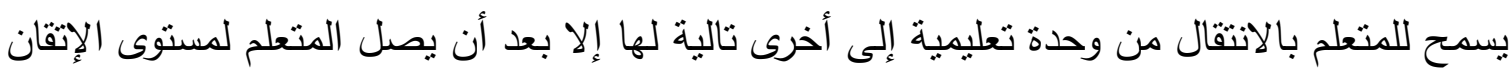

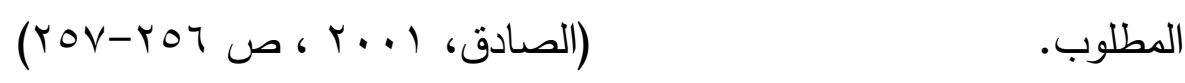

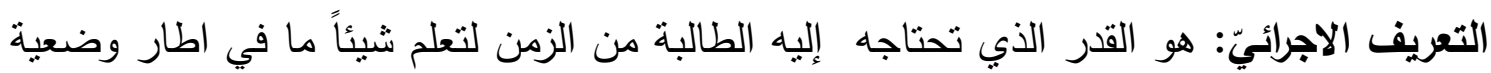

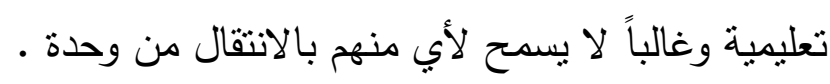

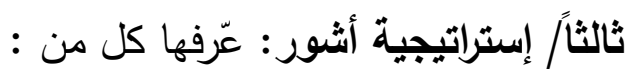
1.(الحيلة): إنَّها تحديد الإجراءات التي يقوم بها المعلم لتخطبط انشطة التلاميذ التعليمية وتوصيلها

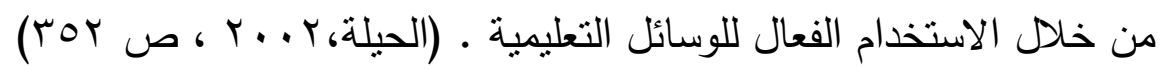

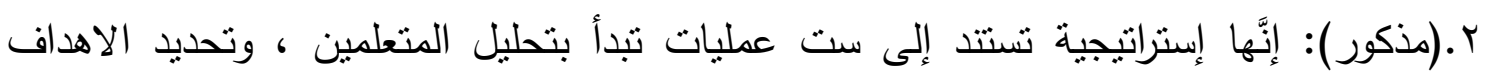

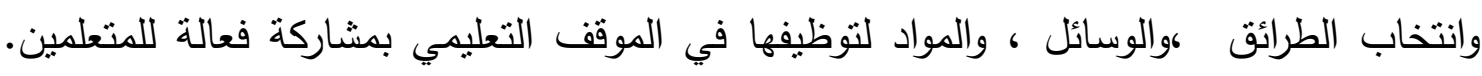

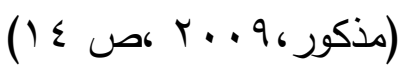

التعريف الإجرائيّ: وهي إستراتيجية اعتمدتها الباحثة لتدريس طالبات المجموعة التجريبية الثانية من

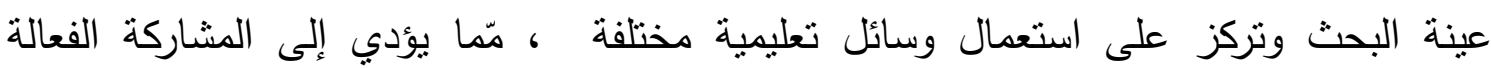
للطالبات ، وتحفيزهن للدرس.

رابعاً/ قواعد اللغة العربية : عُرفه كل من:

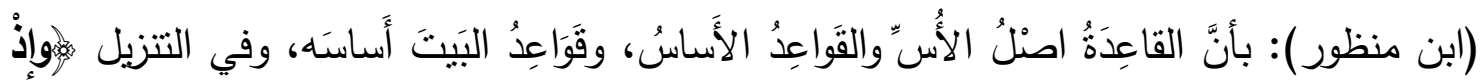

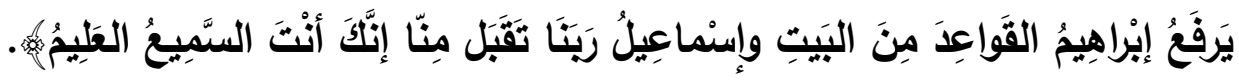

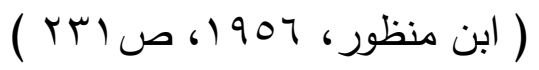




\section{التعريف الاصطلاحيّ للقواعد عَرفها:}

ا ( أبو عجيمة ) : بأنّا ما يعني بالإعراب وقواعد تركيب الجملة ، أسمية كانت أم فعلية ، مثنته

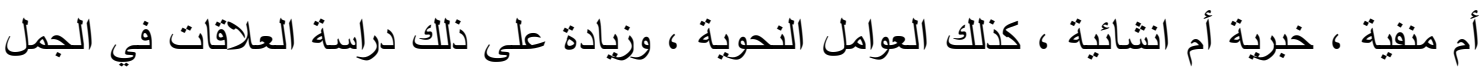

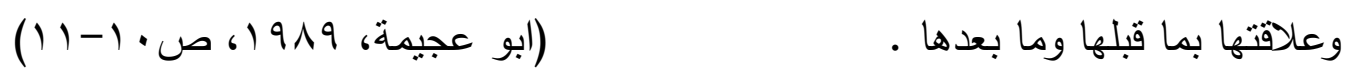

التعريف الاجرائيّ : يقصد بها المادة الدراسية المقررة لتدريس قواعد اللغة العربية التي يحتويها

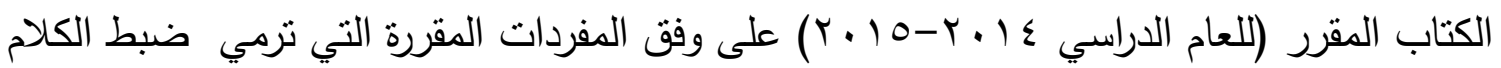
وصحة النطق والكتابة . الصف الخامس الأدبيّ:اعتمدت الباحثة على تعريف ( وزارة التربية ): هو الصف الثاني في المرحلة الثانوية التي تمند ثلاث سنوات ، وتلي المرحلة المتوسطة التي أمدها

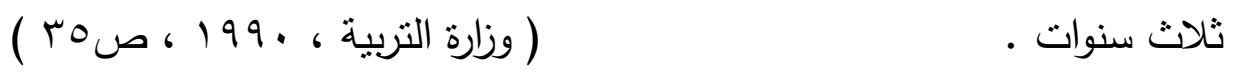

الفصل الثاني/ جوانب نظرية ودراسات سابقة أولاً :الجوانب النظرية 1- استراتيجية كارول ( إتقان التعلم ) :

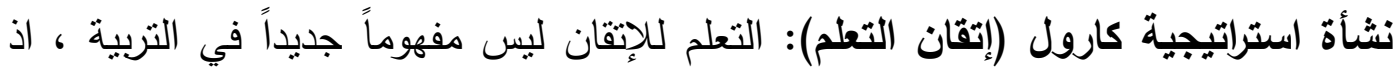

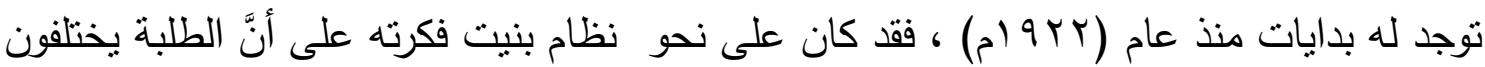

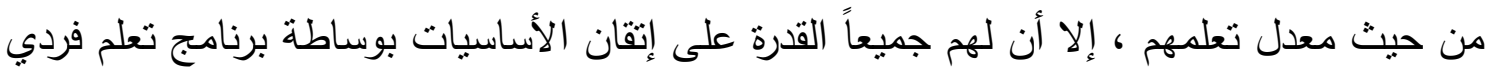
يتفاوت فيه زمن التعلم بحسب اختلاف المعدل الطبيعي لسير الطلاب فيه ، وقد يكون من الصعب

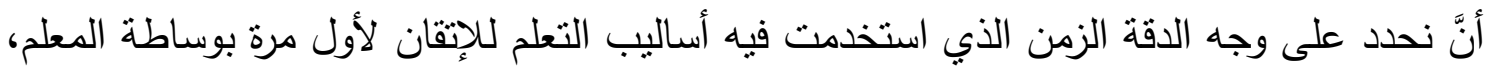

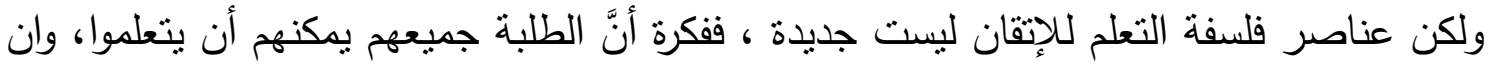
يتعلموا على نحو جيد، وجدت في كتابات المربين الأوائل من أمثال (كومينوس)، و (بسيتالوزي)،

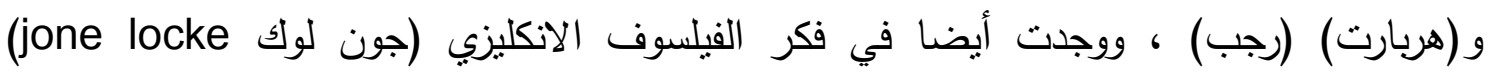

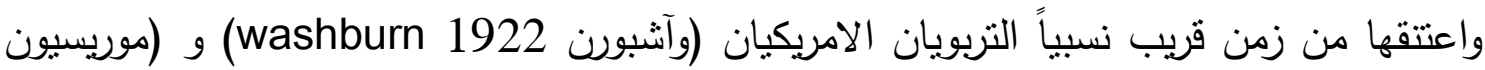

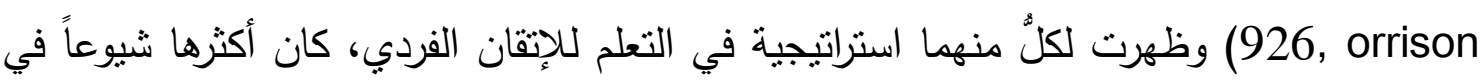
الثلاثثنيات من القرن العشرين استراتيجية (موريسون Morrison ولكن الافتقار إلى التكنولوجيا

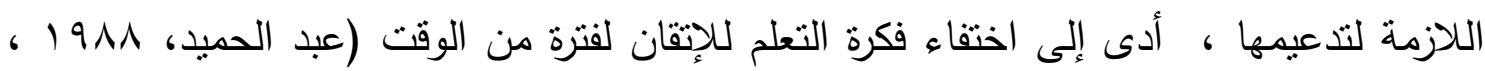




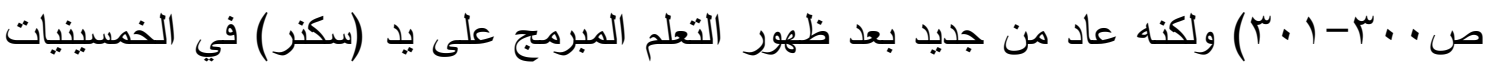

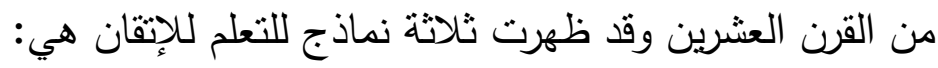

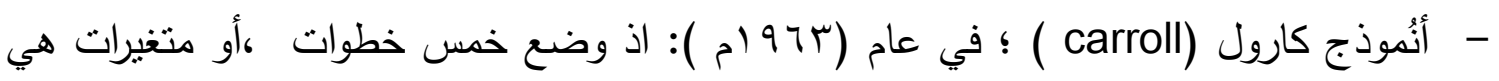
الاستعداد ، ونوعية التدريس ، والقدرة على فهم التدريس ، والمثابرة ، والفرصة.

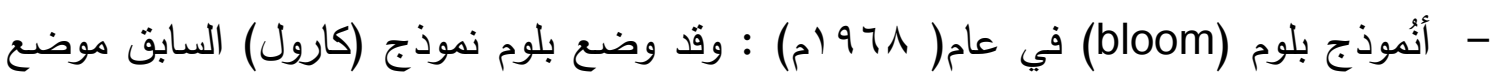
التنفيذ.

- أنُموذج بلوك (block ) في عام( (9V) (م)): أدخل بعض التحسينات في نموذج (بلوم) ونقحت

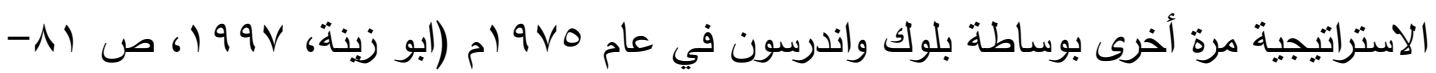

الافتراضات التي تقوم عليها استراتيجية كارول (اتقان التعلم):

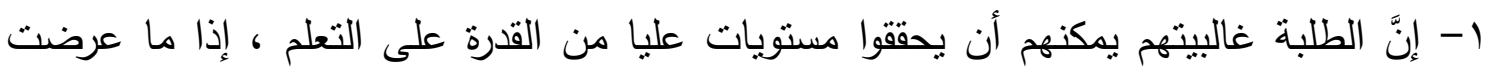

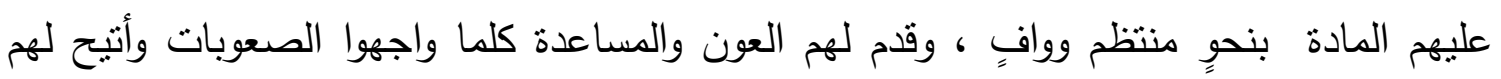
الوقت الكافي لإحراز التمكن في ضوء محك واضح ، بقاس التمكن على أساسه.

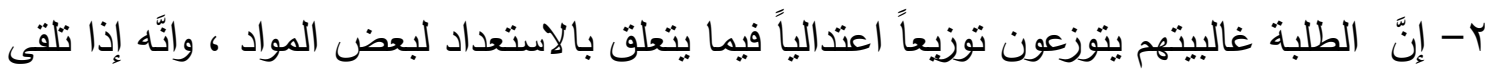

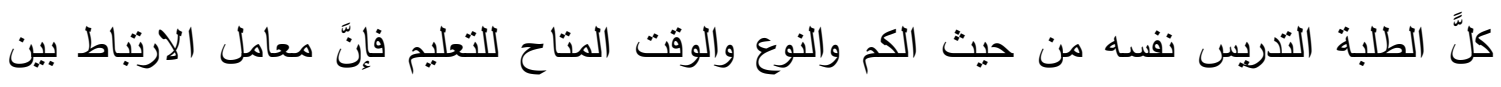
التحصيل والاستعداد سيكون مرتفعاً ، بعكس ما إذا كانت كمية التدريس ونوعه ، والوقت المتاح التهاح

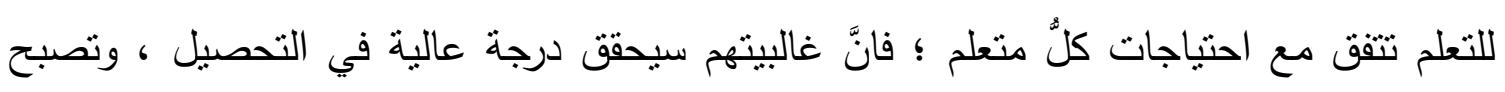
العلاقة بين التحصيل والاستعداد ضعيفة.

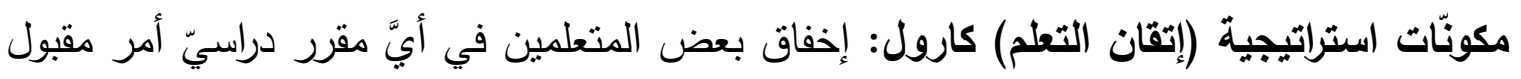

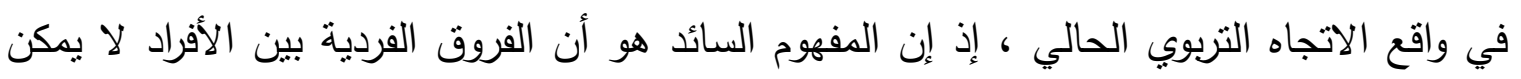

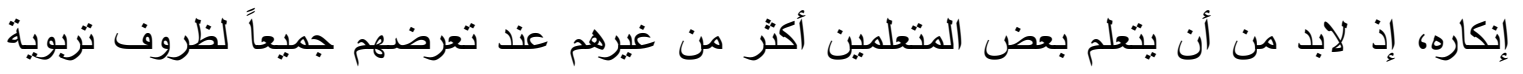

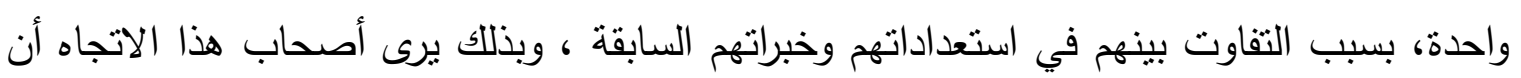

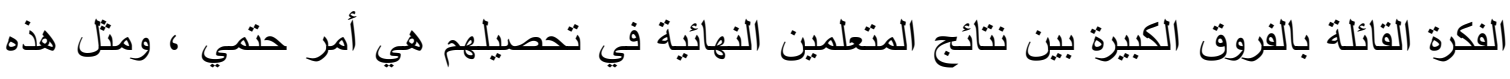

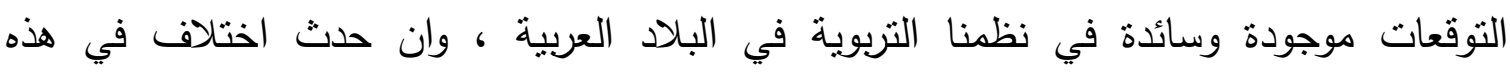

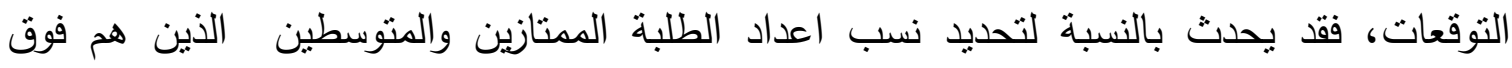

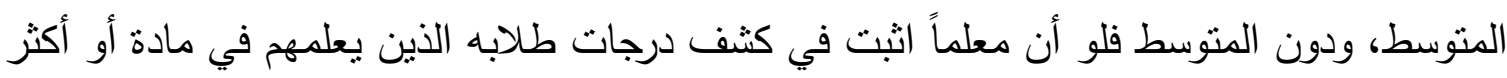
أن تسعين في المائة منهم حصلوا على معدل تسعين في المائة من الدرجات نتيجة امتحاناتهم ، 
لاستهن ذللك منه كثير من المربين وحتى من أفراد المجتمع ، الذي يقبل منه أن يثبت في كثف

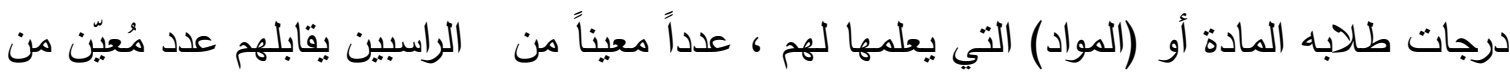

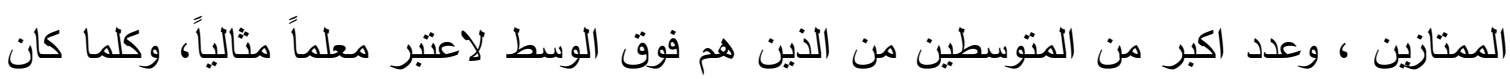

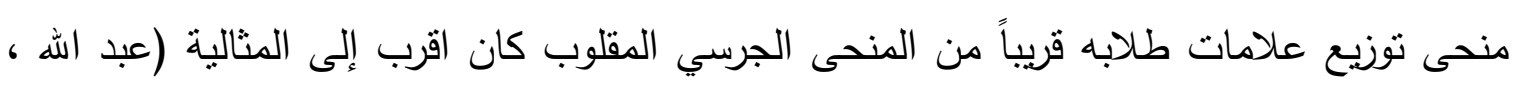

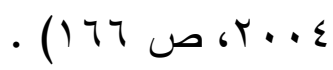

مكّونات التعلم للإتقان ، بحسب وصف "كارول" لها:

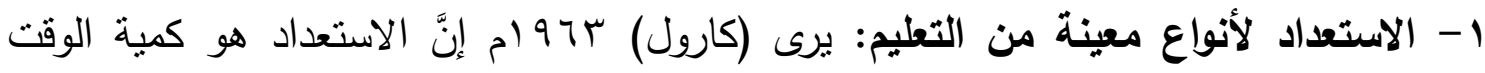

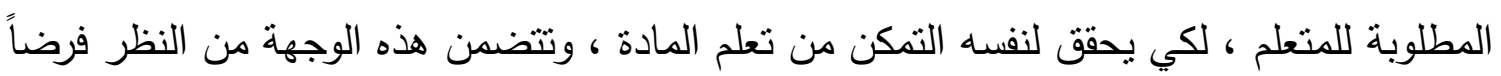

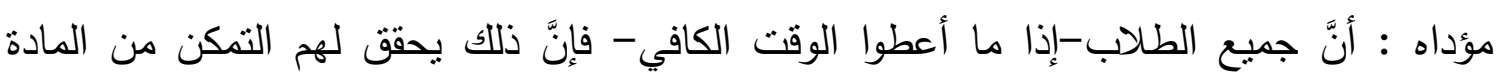
المطلوبة، فإذا كانت وجهة نظر (كارول) صحيحة ؛ فان التعلم للتمكن يكون من الناحية النظرية

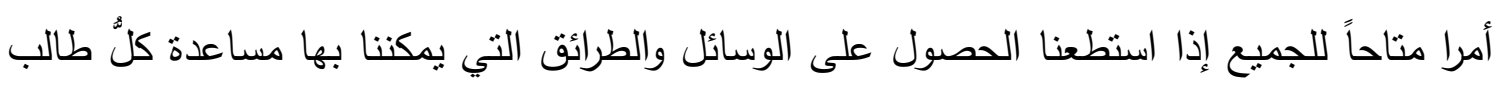

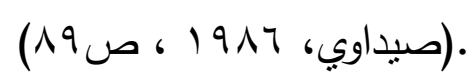

r-نوعية التدريس: إنَّ الطلبة يحتاجون إلى أنماط مختلفة جداً من التدريس ، والى نوعيات مختلفة

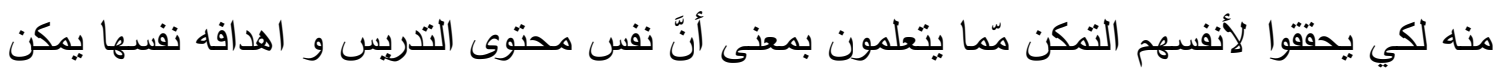

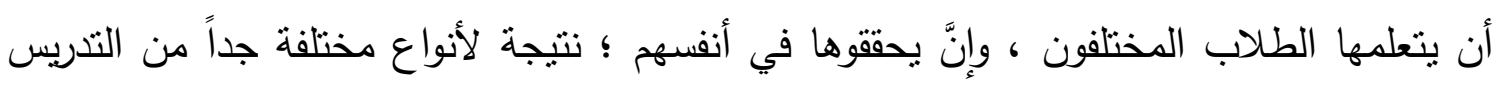
ويعرف (كارولrا79 (م) نوعية التدريس في ضوء مدى اقتراب عرض عناصر العمل وتوضيحها

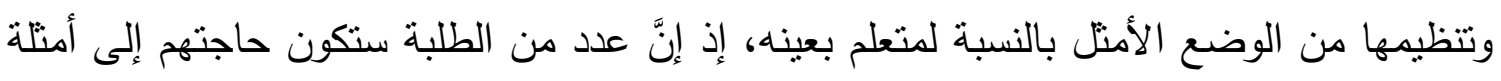
توضيحية وشروح محسوسة ملموسة أثند من حاجة غيرهم الى ذلك. بلك.

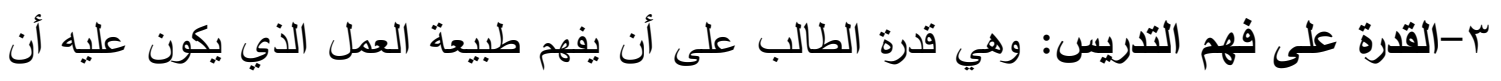
يتعلمه والطرائق التي عليه أن يتبعها في تعلم هذا العمل ، وهذه هي النقطة التي تتفاعل فيها قدرات

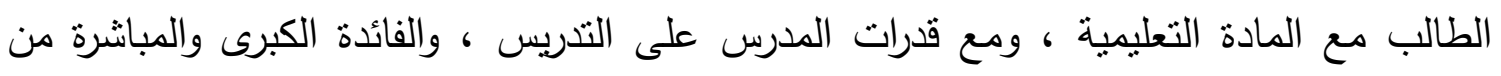

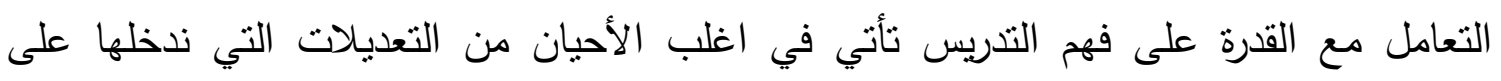

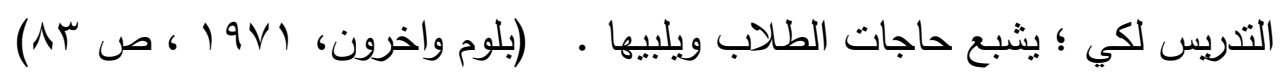

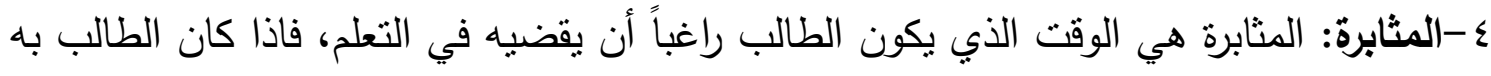

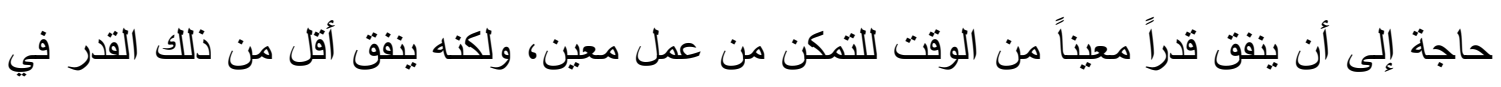

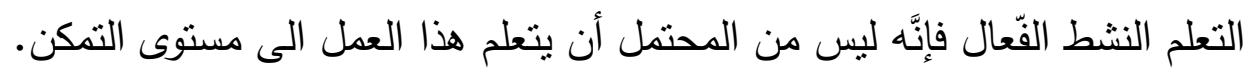


نشأة استراتيجية آشور: صمم هذه الاستراتيجية كلُ من (روبرت هنبش، وميشال مولندا) من

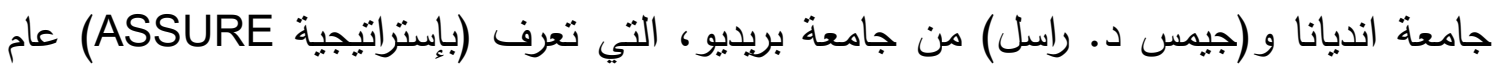

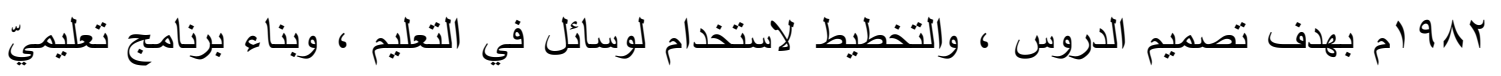

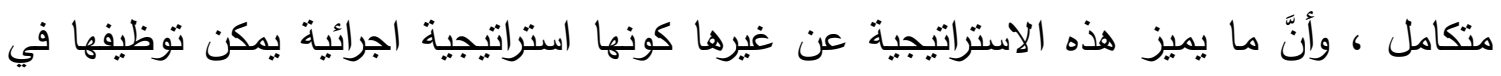
عمليات التخطيط للارس ؛ بقصد ضمان الاستعمال الفعّال للوسائل التعليمية من قبل المعلم داخل هلئل

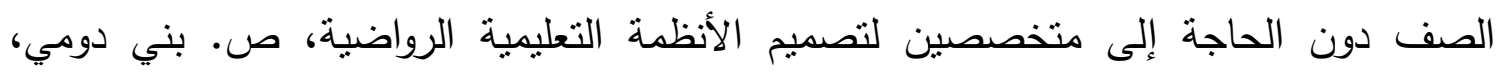

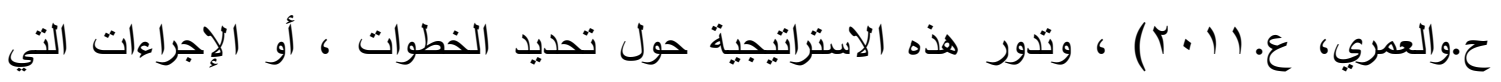

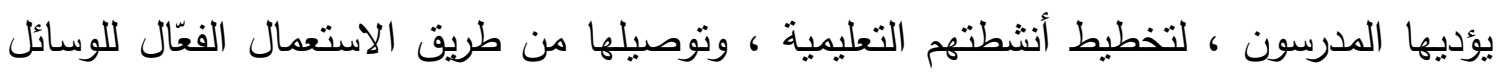

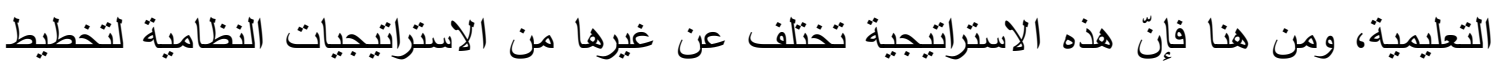

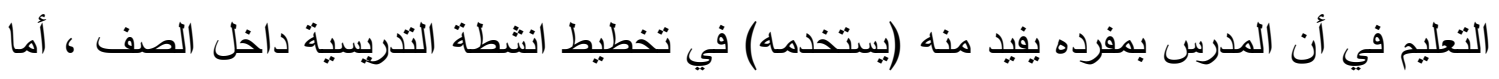
الاستراتيجيات الأخرى ؛ فتحتاج إلى فريق من المتخصصين ، لتصنيف لتصميم الأمور المتعلقة بالأنظمة

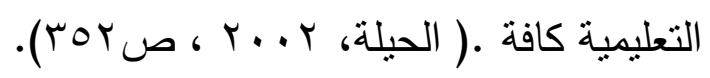
خطوات تصميم الوسائل التعليمية حسب استراتيجية آثور asuure startegg. 1- تحليل خصائص المتعمين: تتضمن تحديد من هم المتعلمون، أو المتدربون من اجل اختيار

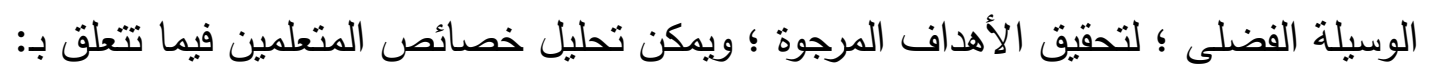
أ-الخصائص العامة للمتعمين، كأعمارهم ؛ ومستوياتهم التعليمبة (صفوفهم) والمستويات الثقافية والاجتماعية والاقتصادية. ب-قدرات مدخلية محدودة (معينة) لمعرفتهم السابقة ؛ ومهاراتهم السابقة، مثناً مهارات رياضية معينة مهارة الجمع قبل الضرب ، او مهارة كتابة الكلمات قبل كتابة جملة. ج-وضع صياغة الأهداف: تتضمن هذه الخطوة وضع الأهداف السلوكية المرغوب تحقيقها بشكل التهل

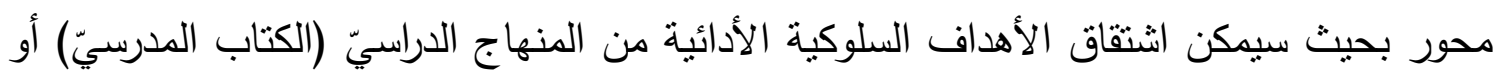

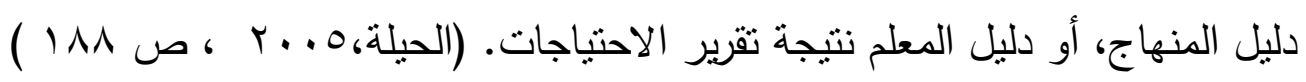

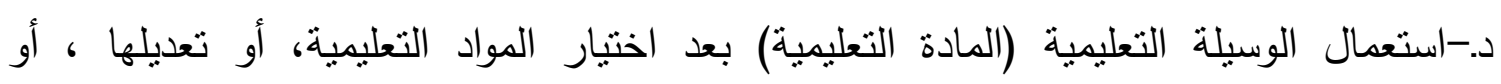

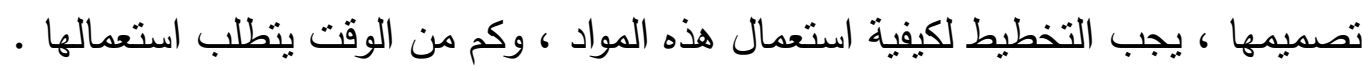

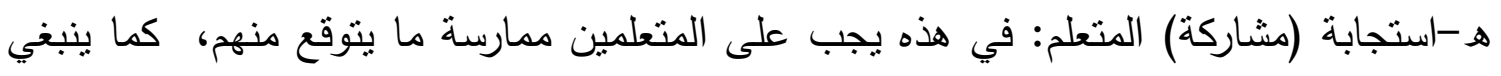

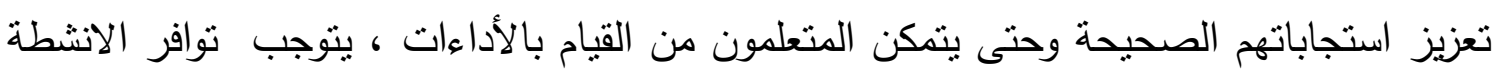


خلا الحصص الصفية ، تسمح لهم بالمشاركة ، أو الممارسة ، وتزويدهم بالتغذية الفورية حول مدى ملائمة أدائهم واستجاباتهم. و -التقويم والتتقيح.. تقويم فعالية الوسيلة التعليمية: بعد الانتهاء من فعاليات التنريس من الضروري تقويم أثرها وفعاليتها، إذ ينوجب معرفة ما إذا كان المتعلمون قد حققوا من خلال قيامهم بأفعال

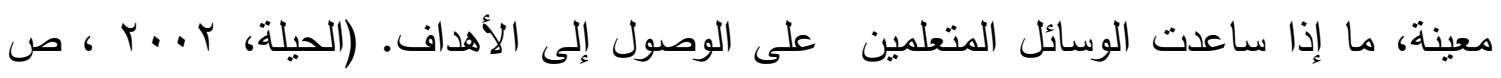
(ror ثانياً/ دراسات سابقة :

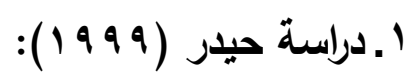

أجريت هذه الدراسة في عمان لمعرفة أثر استخدام استراتيجية التعلم للإتقان على تحصيل طلاب السادس الأساسي في مادة العلوم، و لتحقيق أغراض الدراسة طبق (r ( ) اختباراً تكوينياً

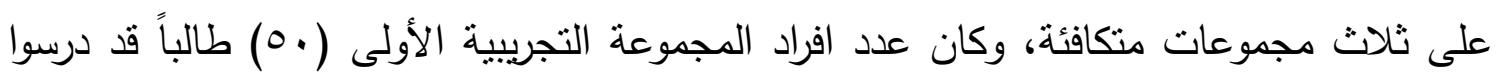

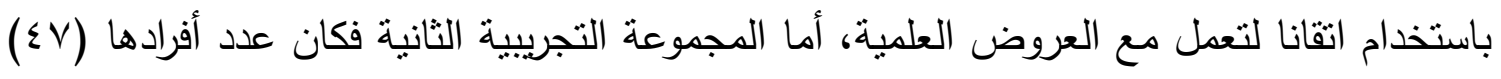

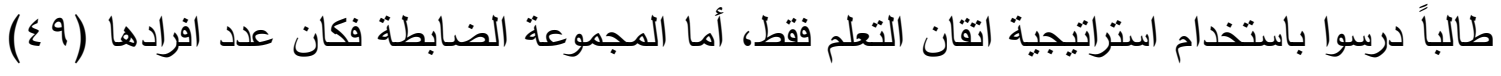
طالباً وقد درسوا باستخدام الطريقة التقليدية، كما حدد الباحث المتغيرات المستقلة بمستويات

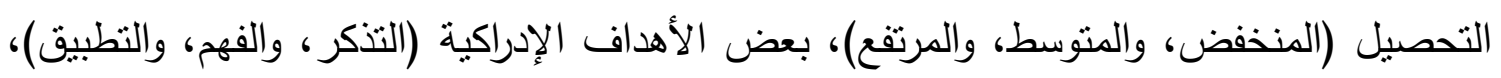

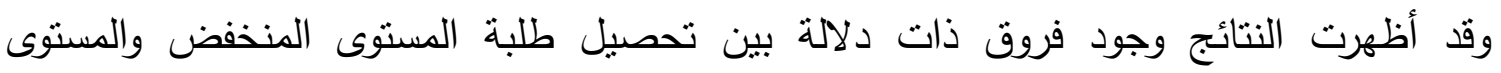

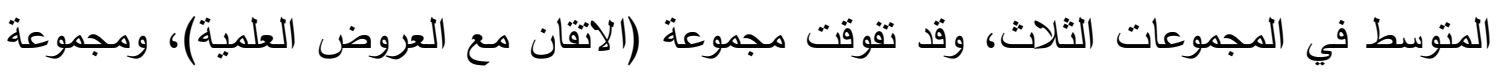
(الاتقان فقط) على المجموعة الضابطة، كما اظهرت نتائج الدراسة عدم وجود فروق ذات ذات دلانلة

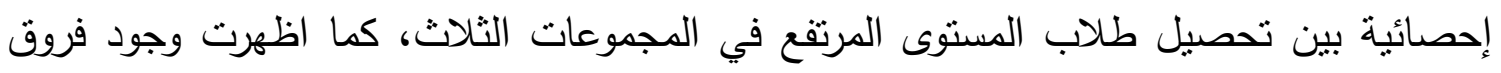
ذات دلالة لصالح مجموعة (الاتقان مع العرض) في مستوى التذكر مقارنة بالمجموعتين الآخريين.

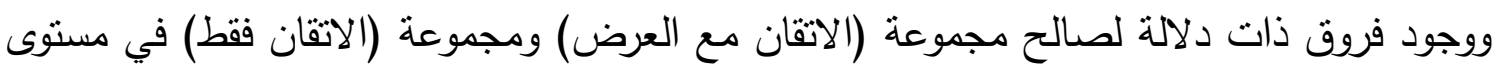
الفهم والموازنة بالمجموعة الضابطة، ووجود فروق ذات دلالة لصالح مجموعة (الاتقان مع العرض)

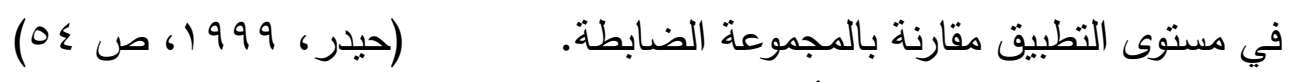

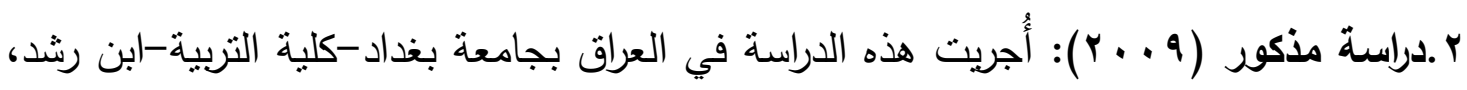
ورمت إلى تعرف "أنز أنموذج دروزة وآثور في تحصيل تلميذات الخامس الابتدائيّ في مادة الجغرافية". اختير التصميم التجريبي ذو الضبط الجزئي (مجموعتان تجريبيتان ومجموعة ضابطة) 
ذات الاختبار البعدي تصميماً تجريبياً لهذه الدراسة، وبلغت عينة البحث (ع V) تلميذة بواقع (Yo) في المجموعة التجريبية الأولى التي درست باستعمال أنموذج دروزه، والمجموعة التجريبية الثانية

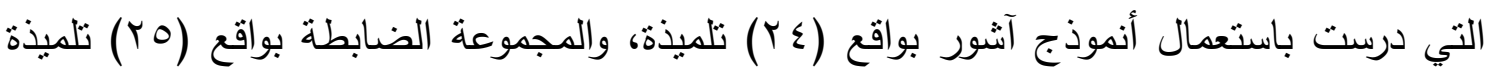
درست بالطريقة الاعتيادية والعمر الزمنيّ، واستخدمت الباحثة التحليل التباين الإحصائي واختبار

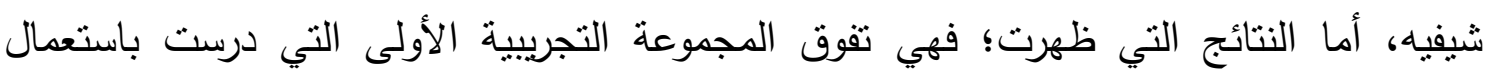
أنموذج دروزة بتحصيل مادة الجغرافية على المجموعة الضابطة التي درست بالطريقة الاعتيادية.

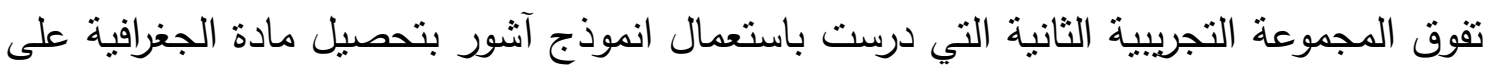

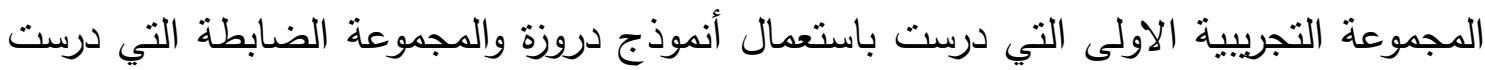

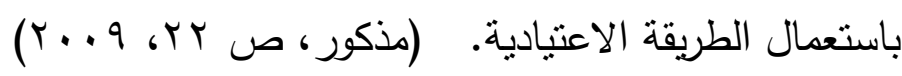
موازنة الدراسات السابقة:

تتوعت أهداف الدراسات، فبينها ما هدفت إلى التعرف على فاعلية استخدام استراتيجية اتقان

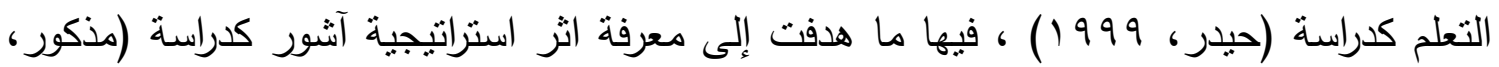

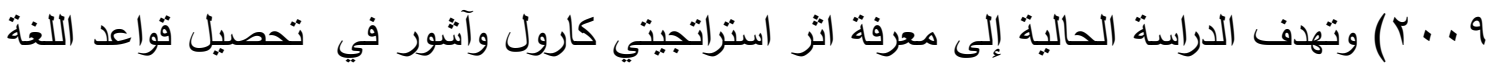
العربية لدى طالبات الصف الخامس الادبيّ ، ولم تقتصر الدراسات السابقة على مرحلة دراسية

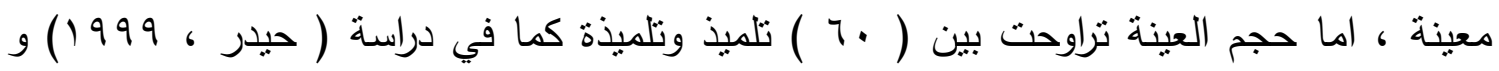

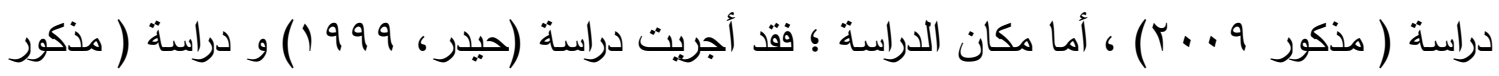

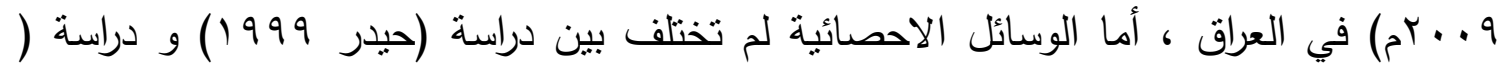
مذكور 9 . . Y) ، حيث اعتمدوا نفس الوسائل الاحصائية التي من طريقها أكدت الدراسات السابقة تفوق أفراد المجموعات التجريبية على أفراد المجموعات الضابطة في التحصيل، وفعالية إستراتيجية كارول (إنقان التعلم) وتفوقها على المجموعة الضابطة . الفصل الثالث/ منهجية البحث وإجراءاته

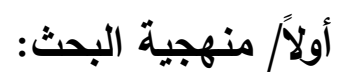
اعتمد البحث على المنهج التجريبيّ الذي يتضمن الإجراءات الآتية: التصميم التجريبيّ: لقد اختارت الباحثة تصميم الهموعات المنكافئة ذات الضبط الجزئيّ، وهو التصميم ذو المجموعتين التجريبية والضابطة ذات الاختبار البعديّ فقط ، من نوع الاختبار التحصيلي ، فقد تم اختيار مجموعتين تجريبيتين ، أحدهما تدريس باستعمال استراتيجية كارل (إتقان 
التعلم) الأخرى باستعمال استراتيجية آثور ، ومجموعة ضابطة ثالثة تدرس بالطريقة التقليدية، ، وكما موضح كما في جدول (1)

جلول (1 )

الثكل الآتي يوضح التصميم التجريبي الأي اتبع في البحث الحالي

\begin{tabular}{|c|c|c|c|}
\hline الأداة & المتغير التابع & المتغير المستقل & المجموعات \\
\hline \multirow{3}{*}{ بادبّار } & \multirow[t]{3}{*}{ التحصيل } & استراتيجية كارول ( اتقان التُطم & التجريبية الاولى \\
\hline & & استراتيجية اشور & التجريبية الثانية \\
\hline & & الطريقة التقليدية & الضابطة \\
\hline
\end{tabular}

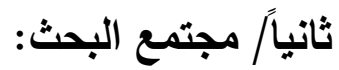

يتمنل مجتمع الدراسة الحالية بطالبات الصف الخامس الأدبيّ في المدارس لثانوية والإعدادية في مدينة بغداد، موزعة على ست مديريات. وبنحوٍ قصديّ؛ اختارت الباحثة المديرية العامة لتربية

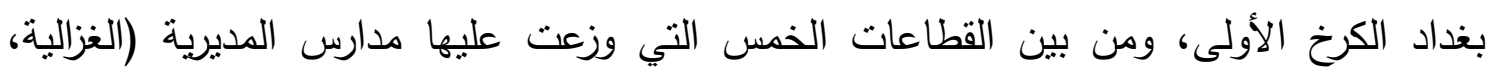

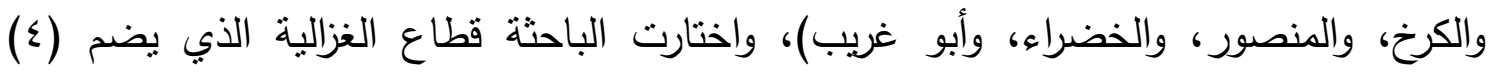

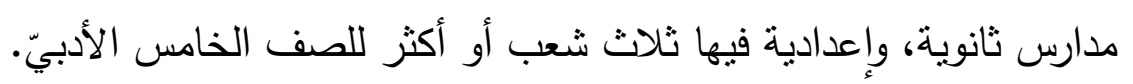

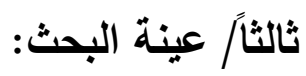

لغرض تطبيق التجربة ، اختارت الباحثة إعدادية الانفال للبنات لتطبيق دراستها التي تضم

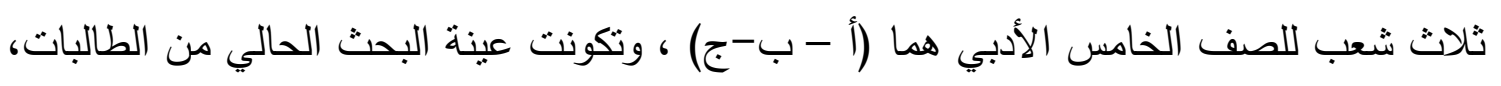

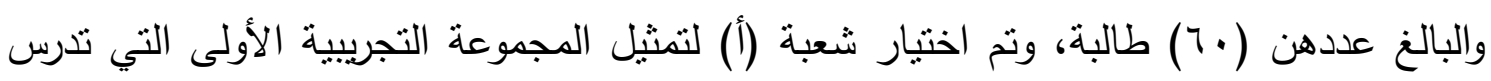

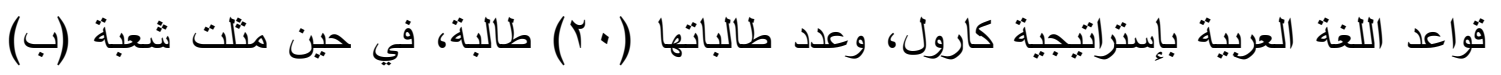

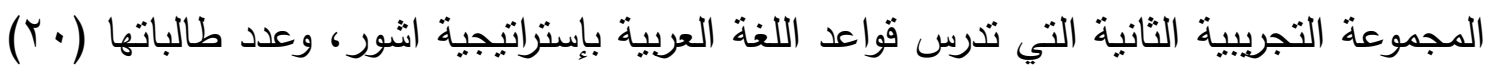
طالبة، في حين منلت شعبة (ج) المجموعة الضابطة التي تدرس قواعد اللغة العربية بالطريقة

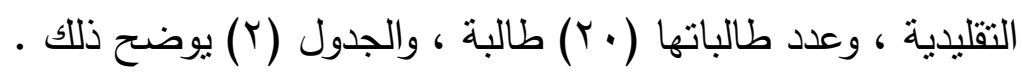

جدول (r)

\begin{tabular}{|c|c|c|c|}
\hline الاستب الطادالبات بعد & الرداسبات الطالبات & عدد الطالبات & المجموعات \\
\hline$r$. & & r. & التجريبية الاولى \\
\hline$r$. & & $r$. & التجريبية الثانية \\
\hline$r$. & & $r$. & الضابطة \\
\hline 7. & & 7. & المجموع \\
\hline
\end{tabular}


رابعاً/ تكافؤ مجموعات الدراسات: حرصت الباحثة على إجراء عملية التكافؤ بين مجموعات الدراسة احصائياً في المتغيرات التي

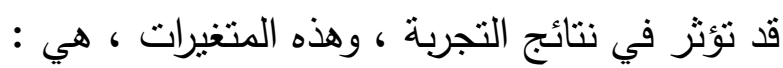

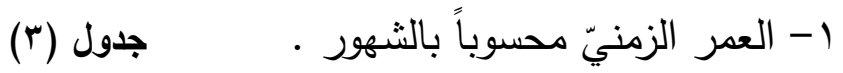
تكافؤ مجموعات الاراسة في متغير العمر الزمني

\begin{tabular}{|c|c|c|c|c|c|c|c|}
\hline \multirow{3}{*}{ الدلالةوى } & \multirow{3}{*}{ الدرجة } & \multicolumn{2}{|c|}{ القيمة التائية } & \multirow{3}{*}{ المعياري } & \multirow{3}{*}{ الحسابي } & \multirow{3}{*}{ العيذة } & \multirow[t]{3}{*}{ المجموعة } \\
\hline & & & & & & & \\
\hline & & الجدولية & المحسوبة & & & & \\
\hline \multirow{3}{*}{ 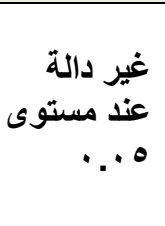 } & \multirow[t]{3}{*}{ ov } & $\bar{r}$ & 1.141 & $V_{.} \cdot \because \Lambda$ & $19 \Lambda . \leqslant \leqslant \wedge$ & $r$. & الاولزريبية \\
\hline & & & & $\varepsilon . V \leqslant Y$ & 194.174 & $r$. & الثانجيةيبية \\
\hline & & & & $0.7 \leqslant 1$ & $19 V .004$ & $r$. & الضابطة \\
\hline
\end{tabular}

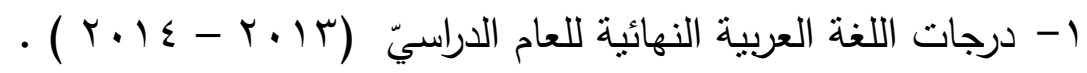

جدول (؛)

\begin{tabular}{|c|c|c|c|c|c|c|c|}
\hline \multirow{2}{*}{ الدلالةوى } & \multirow{2}{*}{ الدرجية } & \multicolumn{2}{|c|}{ القيمة التائية } & \multirow{2}{*}{ المعياري } & \multirow{2}{*}{ الحستوسي } & \multirow{2}{*}{ العينة } & \multirow[t]{2}{*}{ المجموعة } \\
\hline & & الجذولية & المحسوبة & & & & \\
\hline \multirow{3}{*}{ غند ه.. } & \multirow[t]{3}{*}{ ov } & $r$ & $1 . .79$ & $1.1 \wedge 1$ & VO.TY. & r. & التجريبية \\
\hline & & & & $\Lambda_{.} \cdot \wedge_{0}$ & $V \Psi . .74$ & r. & الثانجية التيبية \\
\hline & & & & Q.IAY & $V \varepsilon . V V$ & r. & الضابطة \\
\hline
\end{tabular}

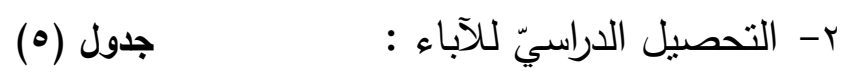

تكافؤ مجموعات البحث في متغير التحصيل الدارسي للآباء

\begin{tabular}{|c|c|c|c|c|c|c|c|c|}
\hline الدالة & كألجدولية & كألهحسوبة & بكلوريوس & 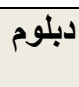 & ثنانوية & ابتائية & امي - ل امي & المجموعة \\
\hline \multirow{3}{*}{ هـير دالة } & \multirow{3}{*}{0.99} & \multirow{3}{*}{ •.Ar } & $r$ & $\xi$ & v & $r$ & $r$ & الاولجىيبية \\
\hline & & & $r$ & 0 & 0 & $\varepsilon$ & $\xi$ & الثانجيةيبية \\
\hline & & & & 7 & 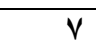 & $\varepsilon$ & r & الضابطة \\
\hline
\end{tabular}




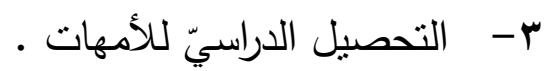

جلول (7) (7)

مريع كاي لتكافؤ المجموعتين التجريبيتين والضابطة لمتغير تحصيل الام

\begin{tabular}{|c|c|c|c|c|c|c|c|c|}
\hline مستوى الدلالة & كالجدولية & كالمحسو بة & بكالوريوس & دبلوم & ثانوية & ابتدائية & أمي & المجمو عة \\
\hline & \multirow{4}{*}{0.99} & \multirow{4}{*}{ T.TE } & $r$ & $r$ & $V$ & 7 & r & التجرييية \\
\hline & & & & & & & & الاولى \\
\hline & & & 8 & $\varepsilon$ & 0 & 1 & 0 & الثانبية \\
\hline & & & $\mu$ & 0 & V & $r$ & $r$ & الضابطة \\
\hline
\end{tabular}

خامساً/ ضبط المتغيرات الاخيلة :

أ ـ اختيار أفراد العينة: حاولت الباحثة الحد من المتغيرات الدخيلة ، باختيار طالبات كلَّ مجموعة

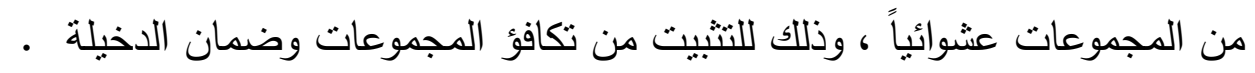

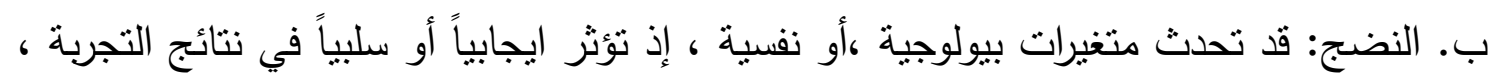

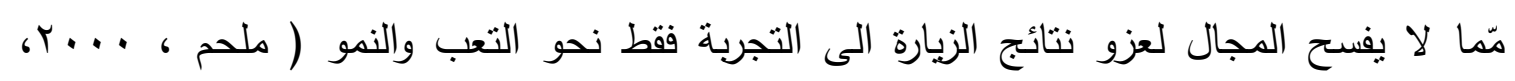

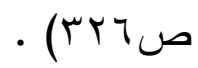

ج. الحوادث المصاحبة : لم يعترض سير التجربة أي طارئ أو حادث من الظروف يعرقل سيرها أو يؤثر في المتغيرين لذا ضبط هذا المتغير .

د. الاندثار التجريبيّ : لم تتعرض الطالبات لظروف معينة لـئ لدا حالات الغيابات الفردية الاعنيادية

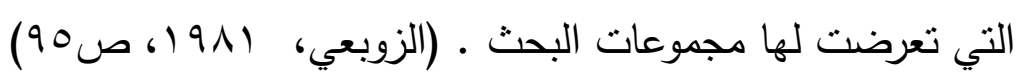
و. أثز الإجراءات التجريبية : ويمثل ذلك فيما يأتي :

أ- سرية التجربة : حرصت الباحثة على سرية التجربة بالاتفاق مع إدارة المدرسة على عدم إخبار

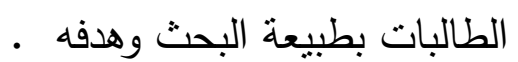

ج-الوسائل التعليمية: حرصت الباحثة على استعمال وسائل تعليمية بشكل منساوي لمجموعات

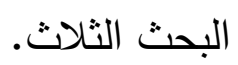

د- مدة التجربة : كانت مدة التجربة موحدة لطالبات المجموعات الثنلاث ، اذ بدأت يوم الاربعاء

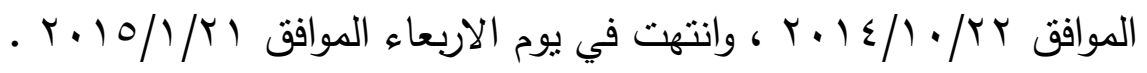
و. توزيع الحصص: ضبطت الباحثة هذا العامل من طريق التوزيع المتساوي للاروس بين

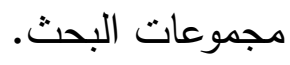


سادساً/ إعداد مستلزمات البحث: ا-صياغة الأهداف السلوكية: تُعَّد صياغة الأهداف السلوكية الخطوة الأساس في بناء أبيَّ برنامج

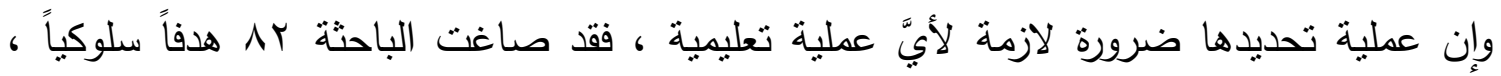

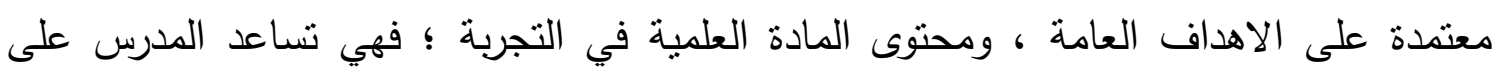
تحديد محتوى المادة المتعلمة ، والعمل على تتظيمها ، و اختيار الطرائق والأساليب التدريسية

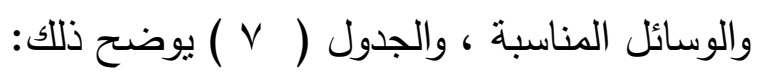

(v) جدول

\begin{tabular}{|c|c|c|c|c|c|}
\hline \multirow[t]{2}{*}{ المجموع } & \multicolumn{3}{|r|}{ السلوكية } & \multirow[t]{2}{*}{ الموضوعات } & \multirow[t]{2}{*}{$ت$} \\
\hline & التطبيق & الفهم & المعرفة & & \\
\hline 17 & 1. & $r$ & $r$ & الضمائر & 1 \\
\hline ir & $\Lambda$ & $r$ & $r$ & اسم المرة و اسم الهيئة & $r$ \\
\hline $1 \cdot$ & $\xi$ & $r$ & $r$ & المصدر الميمي & $r$ \\
\hline$r \cdot$ & Ir & $\varepsilon$ & $\varepsilon$ & اذا - اذ - اي & $\varepsilon$ \\
\hline Ir & 7 & $r$ & $r$ & الحال & 0 \\
\hline 11 & 7 & $r$ & $r$ & التمييز & 7 \\
\hline Ar & $\leqslant 7$ & 11 & 11 & المجموع & \\
\hline
\end{tabular}

r- تحديد المادة العلمية : قبل البدء بالتجربة ، حددت الباحثة المادة العلمية التي ستدرسها في

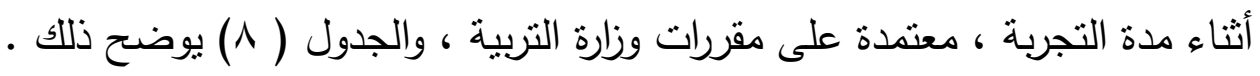

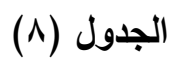

يوضح الأهداف السلوكية لكل موضوع وفي كلَّ مستوى من المستويات الثثلاثة ( المعرفة - والفهر - والتطبيق )

\begin{tabular}{|c|c|c|}
\hline الصفحات & الموضوعات & $ت$ \\
\hline $17-9$ & الضمائر & 1 \\
\hline$Y Y-I V$ & اسم مرة و اسم الهيئة & $r$ \\
\hline$r \cdot-r \mu$ & المصدر الميميّ & $r$ \\
\hline $10-r$ & إذا - إذ - أي & $\varepsilon$ \\
\hline $79-09$ & الحال & 0 \\
\hline$V O-T V$ & التمييز & 7 \\
\hline
\end{tabular}

r- إعداد الدروس أو الخطط النموذجية: يقد بالخطة الدراسية هو تصور عقليّ يصف ما يقوم

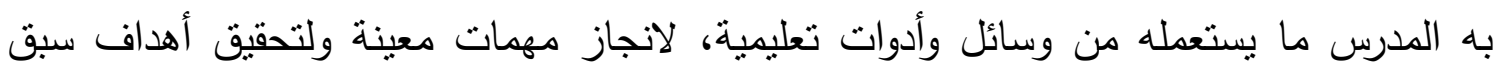

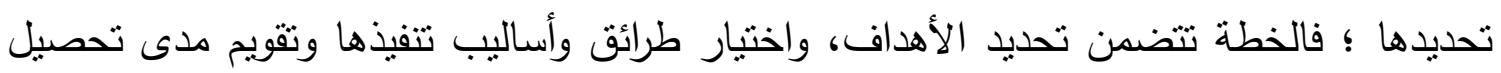


الطلبة لتلك الاهداف (الأمين وآخرون ، 999 19 ، ص سب ())، لذلك أعدت الباحثة دروساً انموذجية

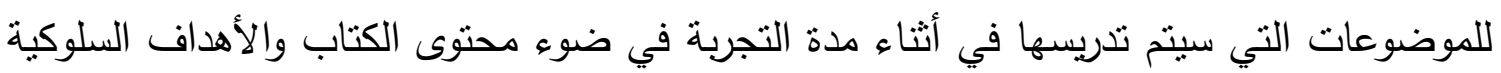
المصاغة ، وعلى وفق استراتيجية كارول للمجموعة التجربيية الأولى ، وعلى وفق استراتيجية آثنور

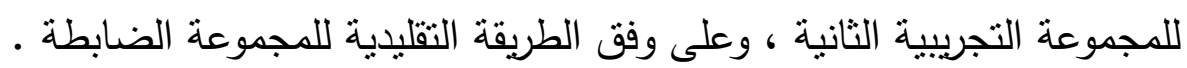

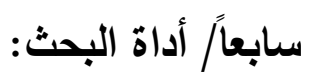
لما كانت هذه الدراسة تتطلب إعداد اختبار تحصيلي لقياس تحصيل طالبات عينة البحث ، لمعرفة تأثير (استراتيجية كارول وأشور) في تحصيلهن ؛ لذلك أعدت الباحثة اختباراً تحصيلياً ، وقد مر هذا الاختبار في مرحلة بنائه بالخطوات الآتية:

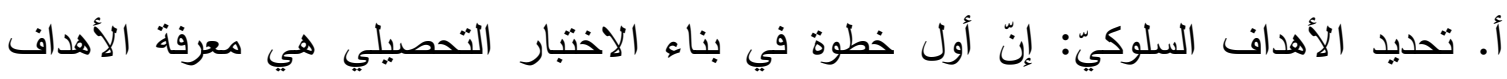

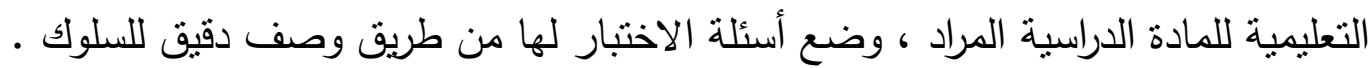

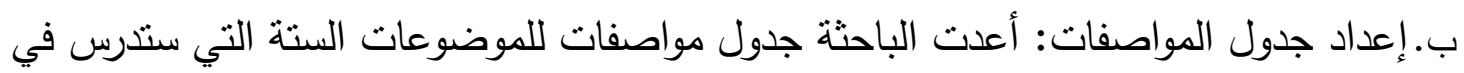

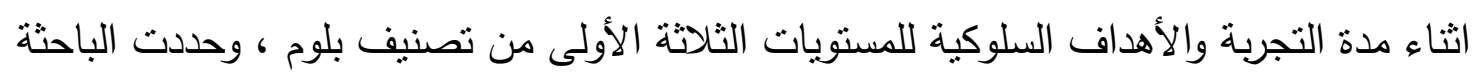

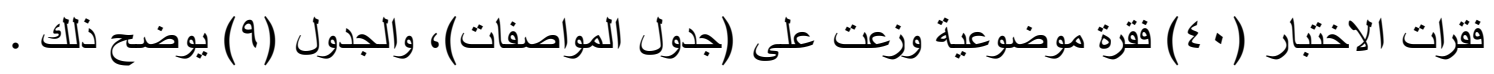
جدول ( ج) (9) الخريطة الاختيارية لإعداد فقرات التحصيليّ لطالبات المجموعات الثلاثة

\begin{tabular}{|c|c|c|c|c|c|c|c|c|c|c|}
\hline \multirow{2}{*}{ ع المجمو } & \multicolumn{3}{|c|}{ عدد الفقرات الاختباري } & \multicolumn{3}{|c|}{ عدد الاهداف } & \multirow{2}{*}{ المحتية } & \multirow{2}{*}{ ألهدتوى } & \multirow[t]{2}{*}{ الموضوعات } & \multirow[t]{2}{*}{$ت$} \\
\hline & تطبيق & فهم & معرفة & تطبيق & فهم & معرفة & & & & \\
\hline$\Lambda$ & $\varepsilon$ & $r$ & $r$ & $1 \cdot$ & $r$ & $r$ & $\% 19$ & 17 & الضمائر & 1 \\
\hline 7 & $r$ & $r$ & 1 & $\mathrm{~V}$ & $r$ & $r$ & $\% \backslash V$ & 14 & اسم المرة والهيئة & $r$ \\
\hline 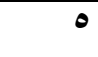 & $r$ & r & 1 & $r$ & $r$ & $r$ & 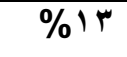 & $1 \cdot$ & المصدر الميمي & $r$ \\
\hline$\Lambda$ & $r$ & $\varepsilon$ & 1 & 0 & 7 & $r$ & $\%$ \% & $r \cdot$ & اذا ـاذـ أي & $\varepsilon$ \\
\hline 7 & $r$ & r & r & $r$ & 0 & $\mu$ & $\% 10$ & Ir & الحال & 0 \\
\hline $\mathrm{V}$ & $r$ & r & r & 0 & 7 & $\mu$ & $\% \backslash r$ & 11 & التمييز & 7 \\
\hline$\varepsilon$. & IV & $1 \leq$ & 9 & $\varepsilon \cdot$ & Yq & 17 & $\% 1 \ldots$ & Ar & المجموع & $\mathrm{v}$ \\
\hline
\end{tabular}

ج. إعداد فقرات اختبار : اعدت الباحثة فقرات الاختبار التحصيليّ لموضوعات قواعد اللغة العربية

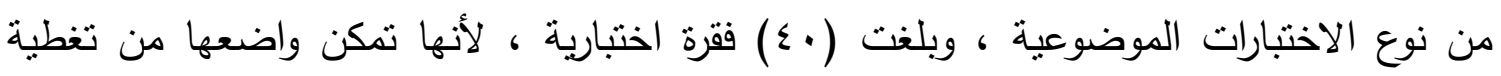

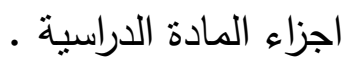


د. واختارت الباحثة فقرات الاختبارات الموضوعية من نوع الاختيار من المتعدد؛ لأنَّها من

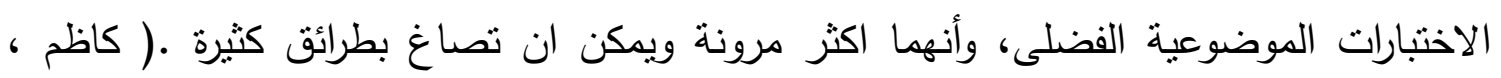

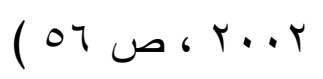
و. التطبيق الاستطلاعية: لغرض معرفة الوقت الذي تستغرقه الطالبات في الإجابة عن فقرات

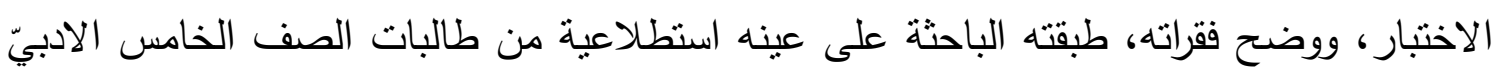

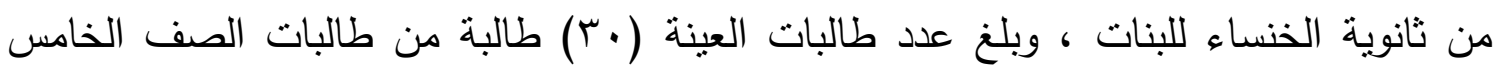

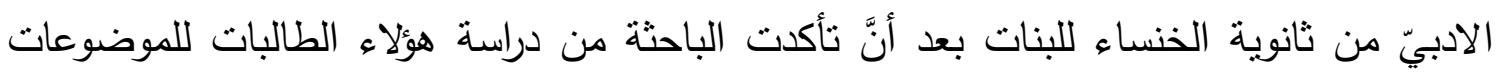

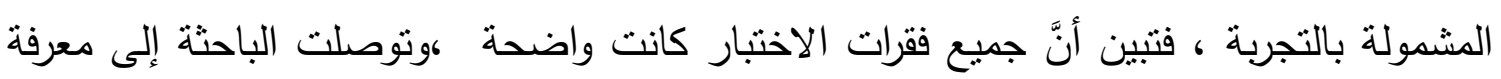

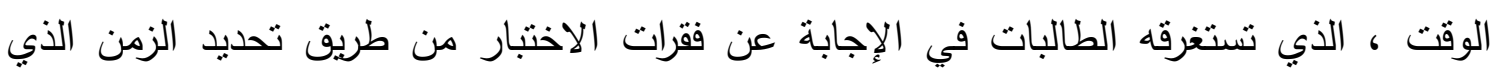

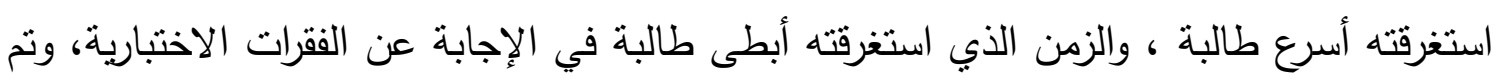

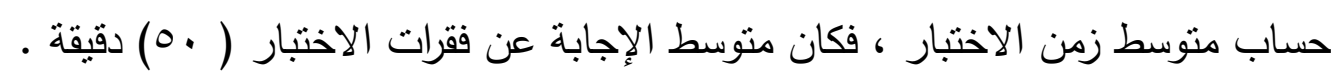

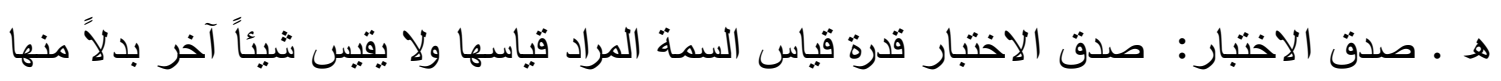

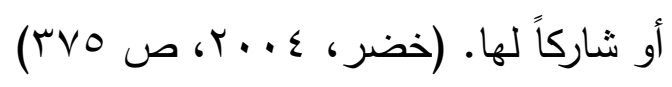

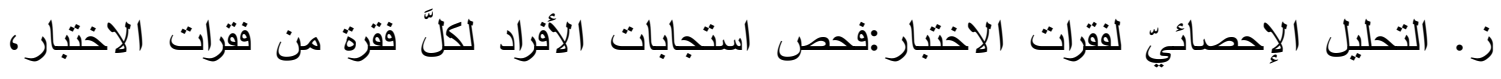

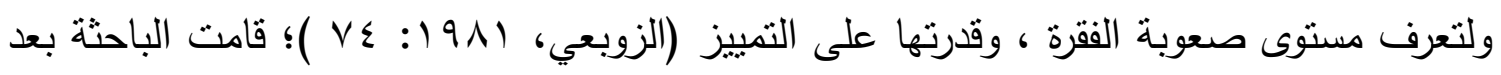

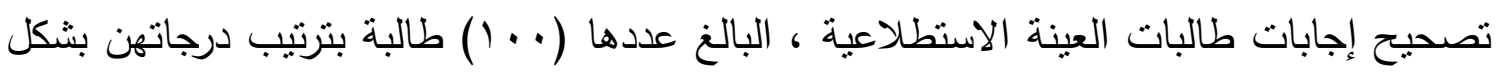

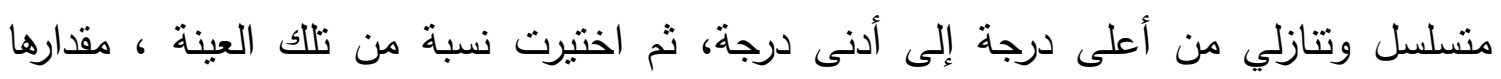

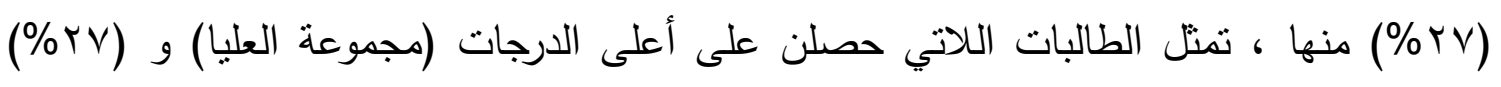

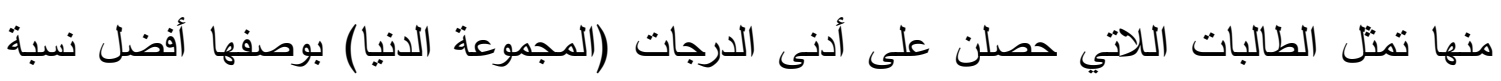
للموازنة بين مجموعتين متباينتين من مجموعة العينة الكلية لدراسة الخصائص السايكومترية الإحصائية . الموانة فين

ا. معامل صعوية الفقرات: بعد حساب معامل الصعوبة لكلَّ فقرة من فقرات الاختبار اتضح أَّنها

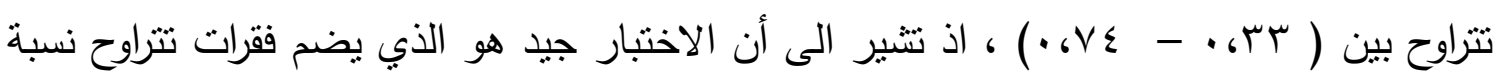

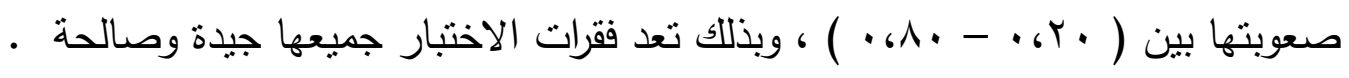

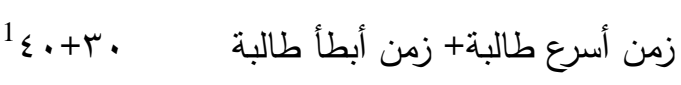

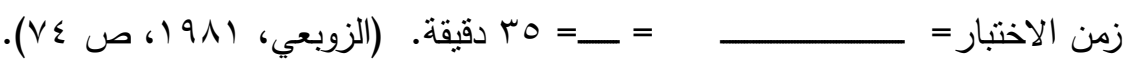


r.معامل التمييز: يقصد بالقوة التمييزية للفقرات مدى قدرتها على التمييز بين الافراد ذوي

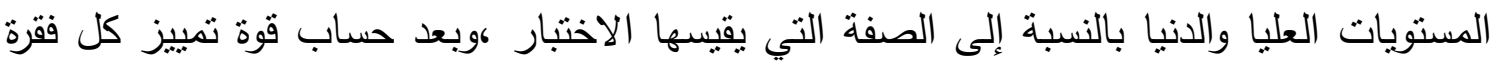

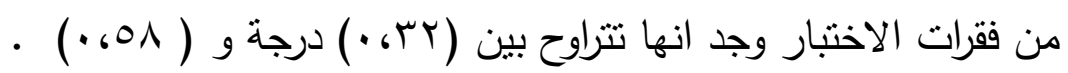

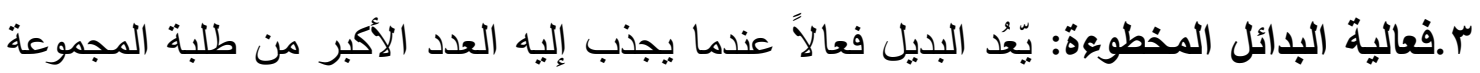
الدنيا بالمقارنة إلى عدد الذين اجتذبوا إليه من طلبة المجموعة العليا ، ويفضل عندما يكون التيه

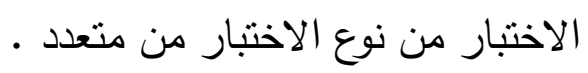
ع. ثبات الاختبار : يقصد بالثبات هو الدرجة التي تكون نتائج أداة القياس ثابتة من مرة إلى أخرى،

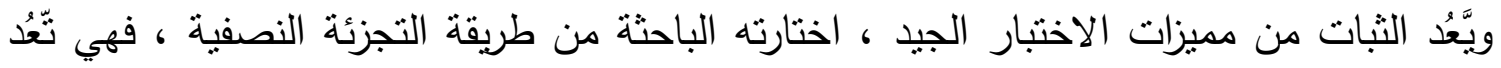

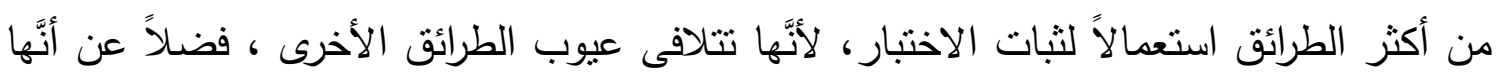

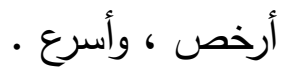

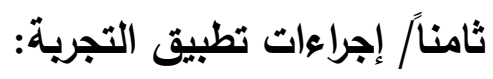
باشرت الباحثة بتطبيق التجربة على طالبات المجموعات التجريبية والضابطة يوم الاربعاء

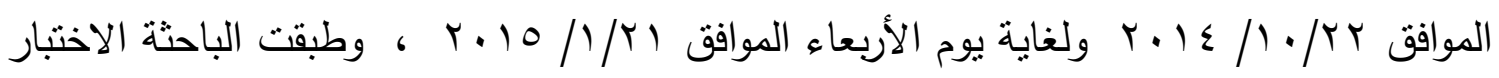

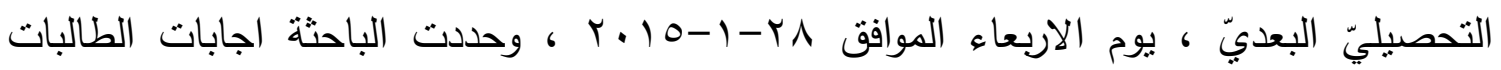

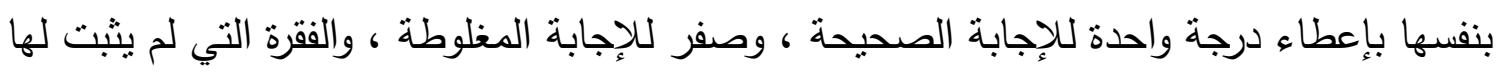

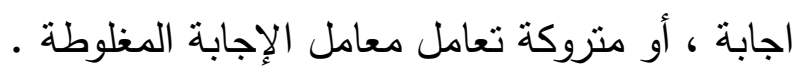
تاسعاً : الوسائل الإحصائية: استعملت الباحثة الوسائل الإحصائية المناسبة في البحث الحئ الحالي وكالآتي: (مربع كاي، ومعامل التمييز، ومعامل الصعوبة، وفعالية البدائل الخاطئة، ومعامل ارتباط

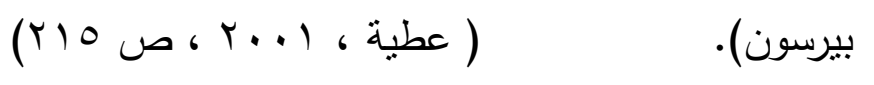

الفصل الرابع/عرض النتائج ومناقشتها: نتائج البحث: تعرض الباحثة هنا النتائج التي توصلت إليها البحث وتحلاها وفي ضوء الإطار النظريّ ، والدراسات السابقة والأدبيات التربوية ، واسنتباط الاستتناجات وتطرح التوصيات التي لني يمكن الاستفادة منها ، والمقترحات التي يجد فيها الباحثون والمعنيون بالمناهج وطرائق التدريس التئسئ مجالاً لإجراء دراسات مكملة لهذه الدراسة. 


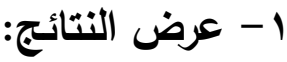

أ- تتص فرضية البحث الاولى على انه (لا يوجد فرق ذو دلالة إحصائية عند مستوى دلالة (0...) بين منوسطات درجات طالبات المجموعة التجريبية الأولى التي تدرس وفق استراتيجية كارول (اتقان التعلم) ومنوسط درجات المجموعة التجريبية الثانية التي تدرس وفق استراتيجية آثور ومتوسط درجات المجموعة الضابطة التي تدرس بالطريقة التقليدية، بعد أن صححت الباحثة

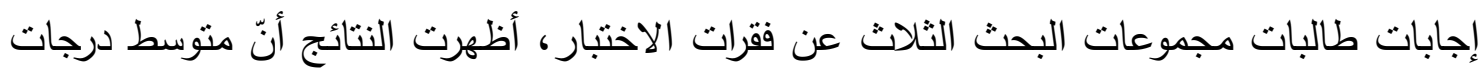
الطالبات عينة البحث كان للمجموعة التجريبية الأولى (10، • r)، وللمجموعة التجريبية الثانية (Y9،79)، وعند استعمال الفرق الاحصائيّ بين متوسط درجات المجموعتين اتضح القيمة التائية

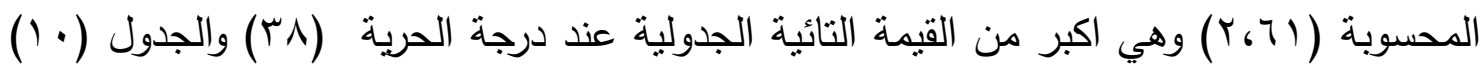
يوضح ذلك.

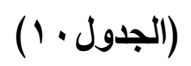

المتوسط الحسابيّ والأنحراف المعياريّ لدرجات والقيمة التائية المحسوية والجدولية لدرجات طالبات المجموعتين

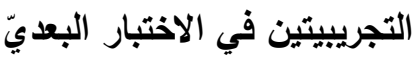

\begin{tabular}{|c|c|c|c|c|c|c|}
\hline \multirow{2}{*}{ الدلالده } & \multicolumn{2}{|c|}{ القيمة التائية } & \multirow{2}{*}{ الحرجية } & \multirow[t]{2}{*}{ المتوسط الحسابي } & \multirow[t]{2}{*}{ حجم العينة } & \multirow[t]{2}{*}{ المجموعة } \\
\hline & الجاولية & الحسوبة & & & & \\
\hline عند & & & $r_{\Lambda}$ & $r \cdot 170$ & $r$. & التجريبية الأولى \\
\hline مستوى & r & Y.T & & Y4.79 & $r$. & التجريبية الثانيةً \\
\hline
\end{tabular}

وتعزو الباحثة السبب في ذلك إلى أحد الأسباب الآتية : ا. إنَّ التدريس باستعمال استراتيجية كارول ( التعلم بالإتقان ) يشخص بعض المشكلات التي

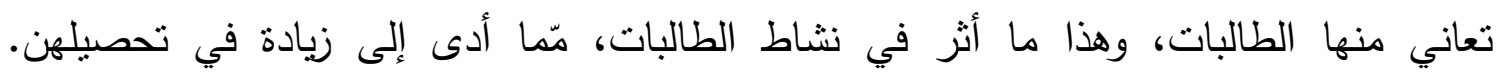
r. إنَّ النَّربس باستعمال إستراتيجية كارول (انقان التعلم) يساعد على جعل التعلم والتعليم تعاونياً،

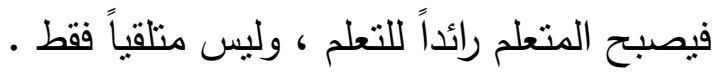
ب- للتحقق من صحة الفرضية الثانية التي نصت على انه ليست هناك فروق ذات دلالة احصائية بين منوسط درجات المجموعة التجريبية الأولى التي تدرس على وفق إستراتيجية كارول (اتقان التعلم) ومنوسط درجات طالبات المجموعة الضابطة التي تدرس بالطريقة التقليدية، صححت الباحثة أوراق الاختبار ، وحلات النتائج فكان منوسط درجات طالبات المجموعة التجريبية 


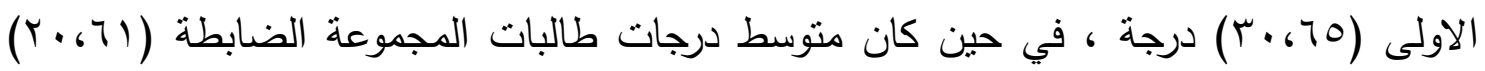
درجة ، وعند استعمال الاختبار التائي لعينتين مستقلنين لمعرفة دلالة الفروق الاحصائية بين

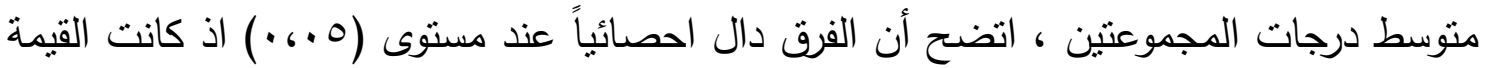

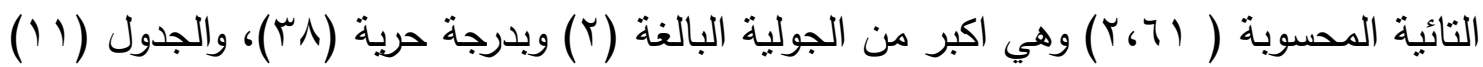
يوضح ذللك.

جدول (11)

المتوسط الحسابيّ والانحراف المعياريّ لارجات والقيمة التائية المحسوية والجدولية لارجات طالبات المجموعة

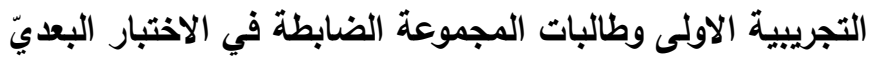

\begin{tabular}{|c|c|c|c|c|c|c|}
\hline \multirow{2}{*}{ الدلاله } & \multicolumn{2}{|c|}{ القيمة التائية } & \multirow{2}{*}{ الدرجة } & \multirow[t]{2}{*}{ المتوسط الحسابي } & \multirow[t]{2}{*}{ حجم العينة } & \multirow[t]{2}{*}{ المجموعة } \\
\hline & الجدولية & الحسوبة & & & & \\
\hline عذد مستوى & r & Y.TI & $r \Lambda$ & $r .670$ & $r$. & التجريبية الأولى \\
\hline ... & & & & $r \cdot(T)$ & r. & الضابطة \\
\hline
\end{tabular}

وقد تعزو الباحثة السبب في ذلك إلى أحد الأسباب التي تم ذكرها عند عرض النتائج الاولى .

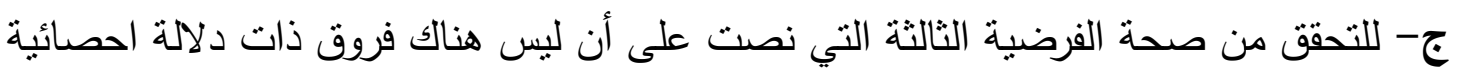

بين منوسط درجات المجموعة التجريبية الثانية التي يدرسن على وفق استراتيجية ( آنثور ) ،

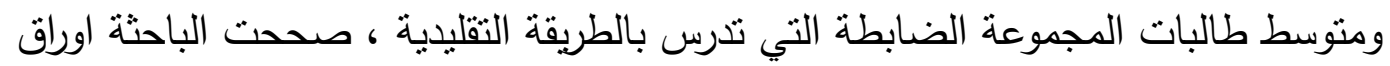

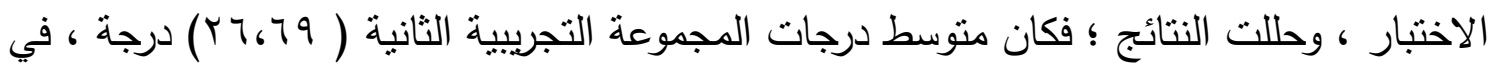

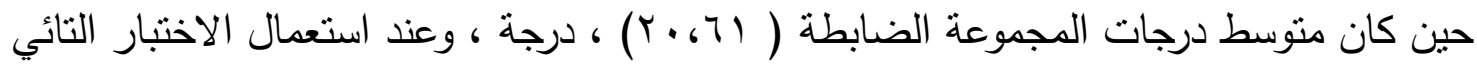

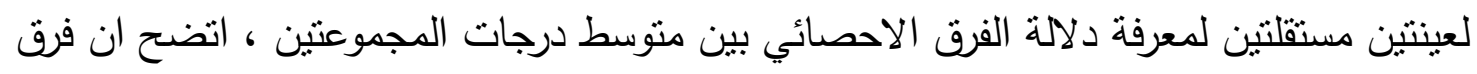

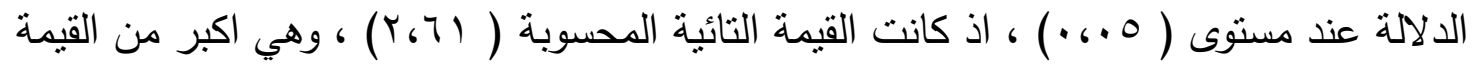

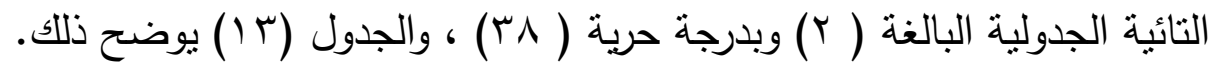

$$
\text { جدول (r) }
$$

المتوسط الحسابي والانحراف المعياري لارجات والقيمة التائية المحسوية ، والجدولية لدرجات طالبات المجموعة

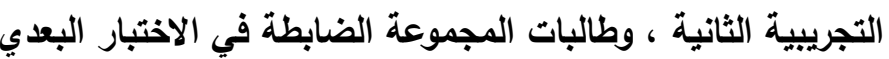

\begin{tabular}{|c|c|c|c|c|c|c|}
\hline \multirow{2}{*}{ الدلاله } & \multicolumn{2}{|c|}{ القيمة التائية } & \multirow{2}{*}{ الحرجة } & \multirow[t]{2}{*}{ المتوسط الحسابي } & \multirow[t]{2}{*}{ حجم العيذة } & \multirow[t]{2}{*}{ المجموعة } \\
\hline & الجدولية & الحسوبة & & & & \\
\hline \multirow{2}{*}{ ه..، . مستوى } & \multirow[t]{2}{*}{ r } & \multirow[t]{2}{*}{ r.7T } & \multirow[t]{2}{*}{ rA } & r9.79 & $r$. & التجريبية الثانية \\
\hline & & & & $r \cdot(T)$ & r. & الضابطة \\
\hline
\end{tabular}


وقد تعزو الباحثة السبب في ذلك إلى أحد الأسباب الآتية:

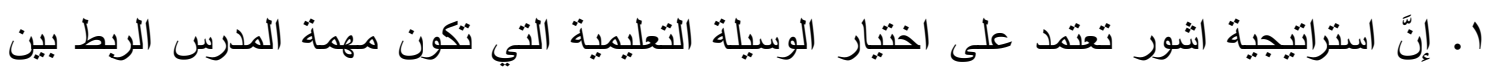

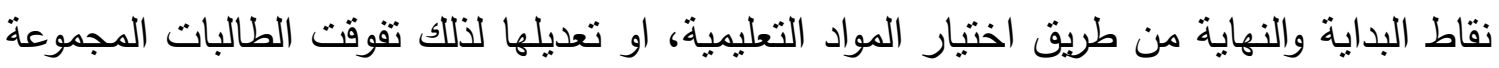

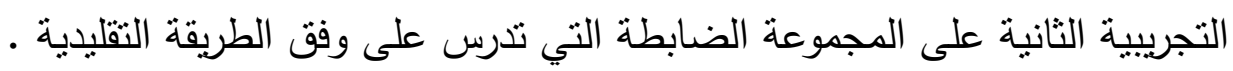
r.إنَّ إستراتيجية اشور تُوجب على المتعلمين ممارسة ما يتوقع منهم ، كما ينبغي تعزيز استجاباتهم

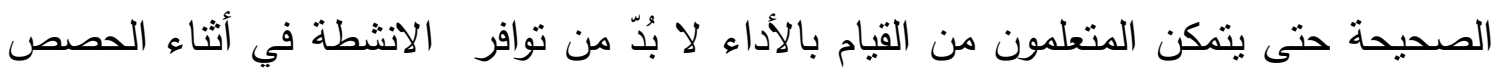
الصفية.

الفصل الخامس/الاستنتاجات والتوصيات والمقترحات:

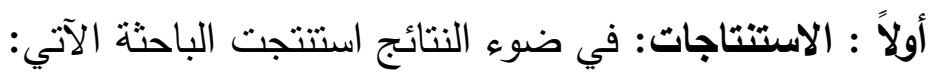

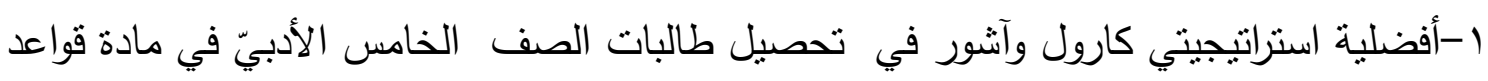

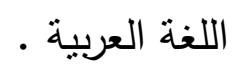
ץ-أفضلية استراتيجيتي كارول وآشور وتفوقهما على الطريقة الاعتيادية في تحقيق تحصيل عالٍ

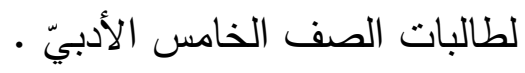
r-إنَّ تطبيق استراتيجيتي كارول وآثور بعث في نفوس الطالبات الحماسة والحيوية ، أسس وأنثاع

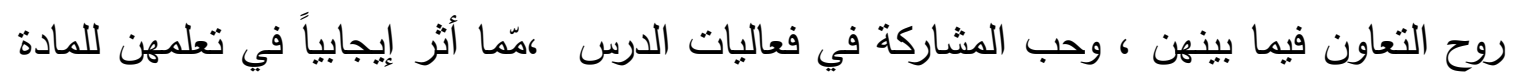
وإنقانها. التوصيات:

في ضوء النتائج التي توصلت إليها الباحثة ، توصي بما يأتي:

1-إقامة دورات تدريبية ، وندوات للمدرسين على كيفية استعمال استراتيجيتي كارول (اتقان التعلم) وآشور على وفق الظروف المتاحة في تدريس المقرر الدراسيّ.

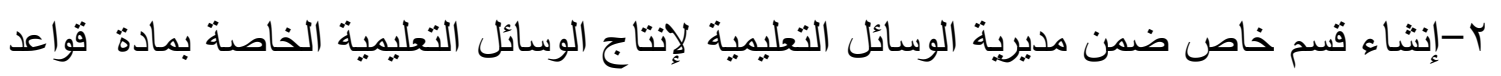

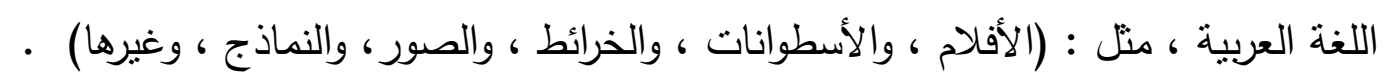

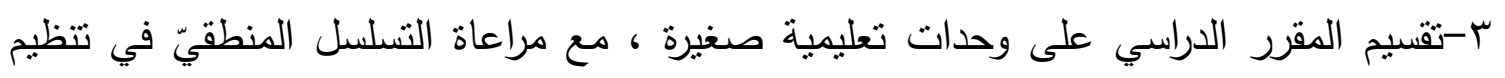
الوحدة التعليمية، منل : جعل الأهداف السلوكية في المقدمة ، تليها الوسائل التعليمية. 
1- إجراء دراسة مماتلة للاراسة الحالية في مادة الادب والنصوص، باستعمال استراتيجتي كارول • واشور r- وإجراء دراسة مماتلة للاراسة الحالية في كليات الآداب في المواد الأخرى الخاصة باللغة العربية .

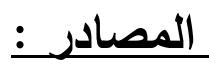

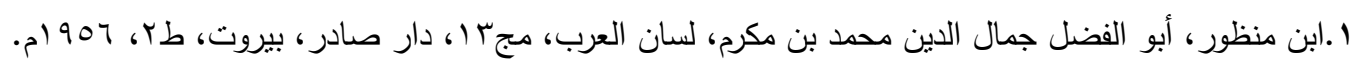

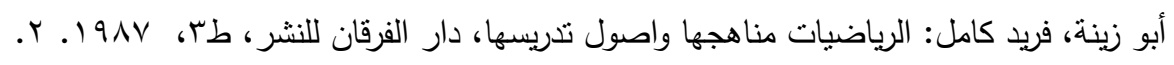

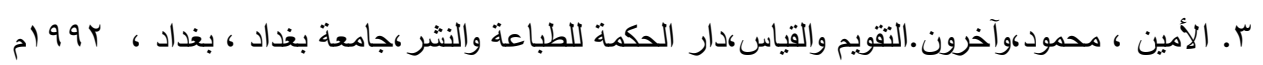

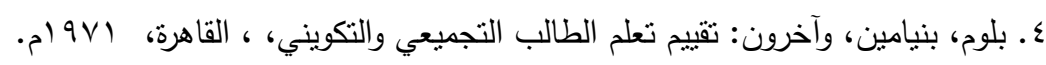

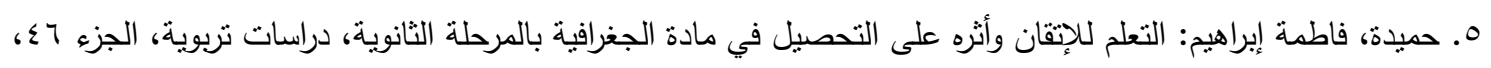

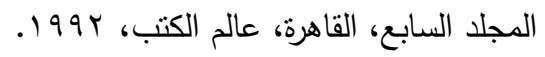

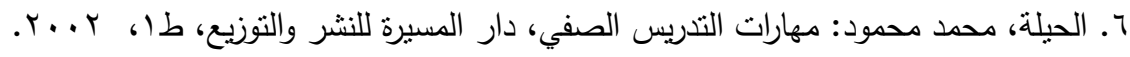

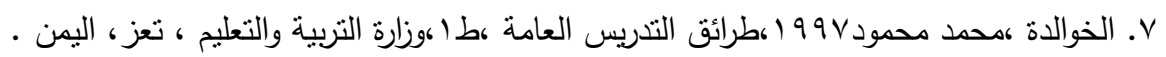

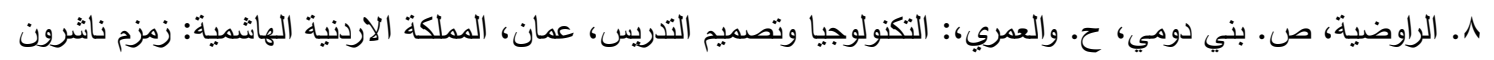

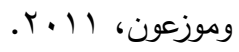
9. زاير ويونس ، سعد علي زاير، ورائد رسم يونس، اللغة العربية - مناهجها وطرائق تدريسها، دار المرتضى للطباعة

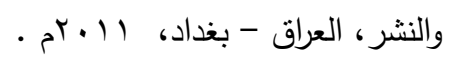

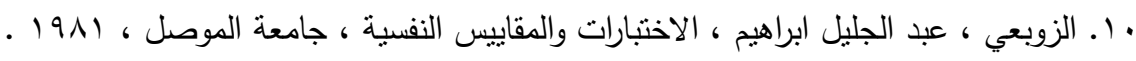

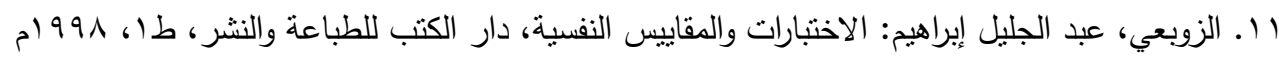

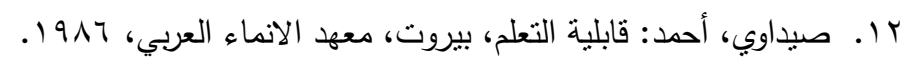

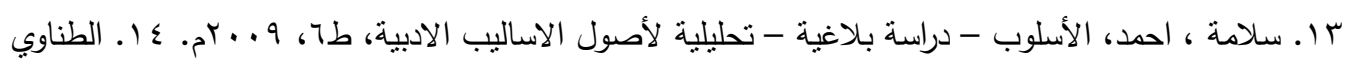

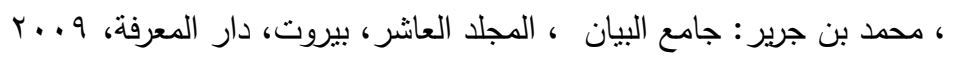

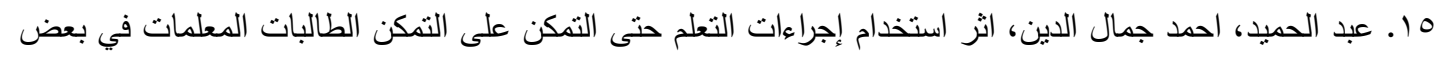

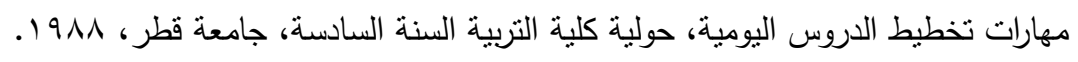

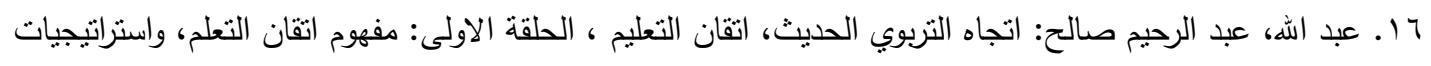

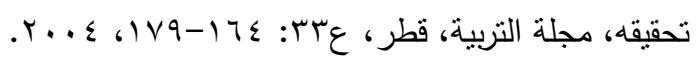

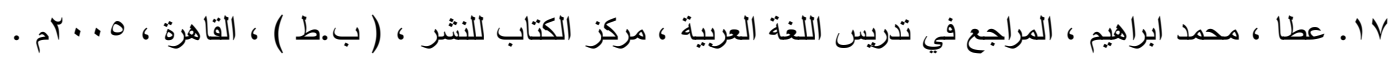
11 ا. عطية، السيد عبد الحميد: التحليل الاحصائي وتطيقاته في دراسات الخدمة الاجتماعية، الككتب الجامعي الحديث،

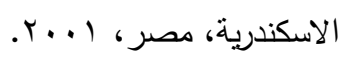




$$
\begin{aligned}
& \text { غلوم ، عائشة عبد الله، قواعد اللغة العربية - أهميتها - ومشكلات تعليمها، مجلة التربية، العدد الخامس، السنة } 19 .
\end{aligned}
$$

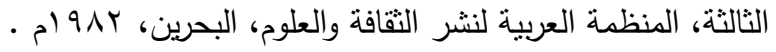

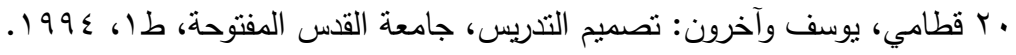

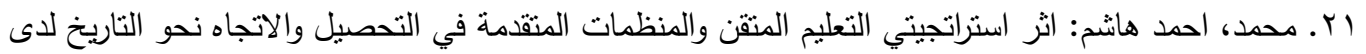

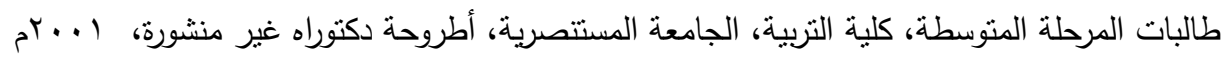

$$
\begin{aligned}
& \text { r r. مذكور ، بشرى حسن: أثر انموذجي دروزه وآتشور في تحصيل تلميذات الصف الخامس الابتدائي في مادة الجغرافية، } \\
& \text { جامعة بغداد، ابن رشد، اطروحة دكتوراه غير منشورة، } 9 \text {. . r. }
\end{aligned}
$$

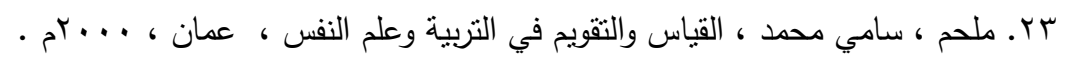

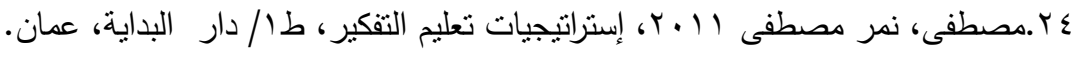

$$
\begin{aligned}
& \text { هץ.النبهان ، موسى ، اساسيات القياس في العلوم السلوكية ، ، عمان ، ع . . آم. }
\end{aligned}
$$

26- Bloom, B.S : Allour children learning, New York: mc Graw-Hill co( 1981).

27-- Bloom, B.S. Learning fornastery comment(1), (2) in New York,( 1968).

\title{
Carol impact strategies and Assyria in the collection of Arabic grammar the students fifth grade literary \\ M.D. Saba Hamid Hussain \\ University of Baghdad / College of Education, Ibn Rushd Human Sciences
}

\begin{abstract}
:
The goal of this research know the effect strategies Carol and Assyria in the collection of fifth-grade students in literary Arabic language rules And used researcher experimental approach, opting deliberate manner sample of students (fifth grade literary) (from the Anfal School for Girls in Baghdad) for the academic year (2014-2015) for the purpose of application of the experiment, has applied researcher testing on an exploratory sample consisted of 30 students from the community Find the same, as she taught the three research groups themselves, and continued the experiment, which began on Sunday 18/01/2015. On a similar sample of the research sample consisted of 100 female students from the fifth literary purpose of the data processing statistically adopted a researcher at the Pearson correlation coefficient, and the coefficient of difficulty, and the power of excellence, and Cronbach's alpha equation Inlight of this, the researcher found the following results:

1. utweigh the students first experimental group, who studied strategy Carroll on the second experimental group students who studied according to Assyria strategy in the collection of literary fifth grade students.

2.outweigh the students the first two experimental groups, who studied the strategy of Carol II, who studied the strategy according to Assyria to the control group, who studied in the traditional way in the collection of students in the fifth literary Arabic: 1.zreference strategies Carol and Assyria andsupremacy on e traditional way in the collection of fifth-grade students in literary Arabic grammar

2.The time period available for teaching the rules in general and focus on objectivity in particular requires a time more than the time available.
\end{abstract}

